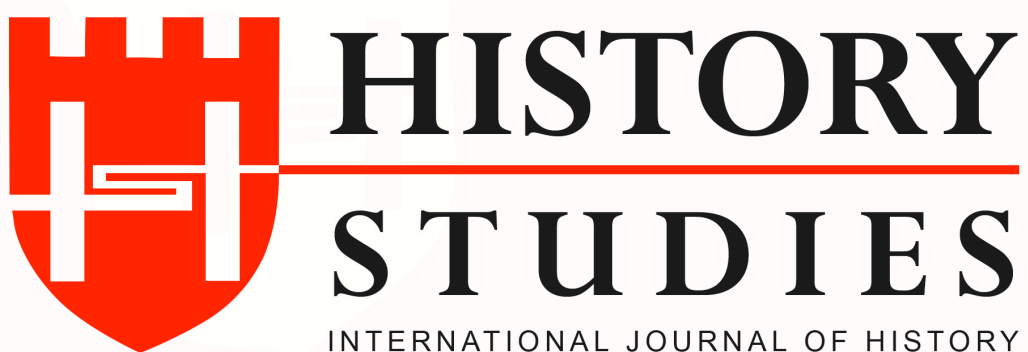

ISSN: 13094173 (Online) 1309 - 4688 (Print)

Volume 11 Issue 2, A Tribute to Prof. Dr. Mehmet Ali ÜNAL, April 2019

DOI Number10.9737/hist.2019.734

Araștırma Makalesi

Makale Geliş Tarihi: 15.01.2019 - Kabul Tarihi: 25.02.2019

Atıf Künyesi: Nurdan Güven Toker, "Cumhuriyetin İlk Yıllarında Toplumla Bütünleşme Projesi Olarak Milli İktisat ve Tasarruf Cemiyeti”, History Studies, 11/2, Nisan 2019, s.655-679.

\title{
Cumhuriyetin İlk Yıllarında Toplumla Bütünleşme Projesi Olarak Milli İktisat ve Tasarruf Cemiyeti
}

National Economy and Savings Society: An Integration Project of the State with the Public in the Early Years of the Turkish Republic

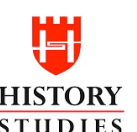

ST UDIES

Volume 11 Issue 2

A tribute to Prof. Dr.

Mehmet Ali ÜNAL

April

2019

\author{
Dr. Nurdan GÜVEN TOKER \\ ORCID No: 0000-0002-4868-0717 \\ Yeditepe Üniversitesi - İstanbul
}

Öz:1930'lu ylllar gerek 1929 yllında patlak veren küresel ekonomik kriz, gerekse de Türk devrimi ekseninde yürütülen modernleşme programlarının toplumsal yansımaları sebebi ile yeni kurulan Türkiye Cumhuriyeti açısından iktisadi ve siyasi alanlarda bir arayıs dönemi olmuștur. Bu dönemin en önemli özelliklerinden biri, üretim ilişkilerinin devletçi iktisat politikası benimsenerek yeniden düzenlenmesidir. Milli İktisat ve Tasarruf Cemiyeti, bu dönüsüm sürecinde devlet politikalart paralelinde halkın yönlendirilmesi görevini üstlenen önemli bir kurum olarak bu çalışmanın konusunu oluşturur. Cemiyetin öncelikli görevi, küresel kriz sebebi ile iktisadi alanda yașanan daralmaya karșllık olarak ithalat dengesinin sağlanması ve sermaye birikimi elde edilebilmesi bakımından halkın tüketim alışkanlıklarını değiştirerek tutumlu bir yaşam biçiminin ve yerli ürün kullanma alıskanlığının topluma yayılması olmuștur. Bu görevinin yanı sıra, cemiyet Türk devrim ilkeleri ile şekillenen devletin egemen ideolojisinin, devam etmekte olan ulus inşa sürecinin bir parçası olarak toplumda kök salması için faaliyet göstermiştir. Bu çalışmada, 1930 'lu yılların devletçilik politikalarının en yoğun uygulandı̆̆ dönemde Milli İktisat ve Tasarruf Cemiyeti, Louis Althusser tarafindan ortaya konulan devletin ideolojik aygıtları kavramlaştırması çerçevesinde ele alınarak, Cemiyetin devletin vermiş olduğu bu misyonu nasıl ve ne şekilde gerçekleştirdiği incelenmiştir.

Anahtar Kelimeler: Milli İktisat ve Tasarruf Cemiyeti, Devletçilik, İktisat ve Tasarruf Dergisi, Tasarruf ve Yerli Malı Haftası, Devletin İdeolojik Aygitları.

Abstract: The 1930s were a period of pursuit in economic and political fields for the newly established Turkish Republic due to both global economic crisis that broke out in 1929 and social reflections of the modernization programs carried out in the axis of Turkish Revolution. One of the most important features of this period is the reorganization of the production ties with the adoption of statist economic policy. The National Economy and Savings Society constitutes the subject of this study as an important institution that undertakes the task of directing people of the Republic in the direction of state policies during this transformation process. The prior task of the Association was to spread the habit of having an economical way of life and preferring national goods by changing the consumption habits of the people in order to achieve a balance of imports and capital accumulation against the economic recession stemming from the global crisis. In addition to this task, the institution was active in order to be sure that, as a part of the ongoing nation-building process of the state, the sovereign ideology seep into the people of the Republic. In this study, how and in what way the National Economy and Savings Society fulfilled the duty given by the state through considering in the axis of the conceptualization of ideological apparatus of the state developed by Louis Althusser in a period when the state policies of the 1930s were applied most intensively was examined.

Keywords: National Economy and Savings Society, Statism, Economics and Saving Magazine, Savings and National Products Week, Ideological Apparatus of the State. 


\section{Giriş}

Osmanlı kalıntıları üzerine kurulan Türkiye Cumhuriyeti'nin, siyasi bağımsızlı̆̆ın kazanılmasının ardından, öncelikli meselelerinden biri iktisadi kalkınma olmuştur. Gerek siyasi otoriteler gerekse dönemin önde gelen aydınları 'ülke nasıl kalkınır' sorunun cevabı üzerine düşünmüşler, bu doğrultuda bazen kısa süreli pratik çözümler getirilmiş, bazen de uzun vadeli planlar yapılmıştır. Şubat ${ }^{1923}$ 'de İzmir'de düzenlenen İktisat Kongresi ${ }^{1}$ ile liberal iktisat politikası izlenmeye karar verilmiş fakat Lozan Antlaşması ile kabul edilen gümrük tarifelerindeki kısıtlamalar ve dış borçlar izlenecek iktisat politikası üzerinde bazı sınırlamalar getirmiştir. ${ }^{2} 1929$ yılında gümrük tarifelerindeki kısıtlamaların sona ermesi ile bir kalkınma hamlesi yapılabileceği sırada, aynı yıl Ekim ayında Amerika Birleşik Devletleri'nde patlak veren ekonomik krizin ${ }^{3}$ küresel bir boyut kazanması Türkiye'yi de önemli ölçüde etkilemiştir. Her ne kadar Batı kapitalist sistemi ile tam anlamıyla bütünleşmemiş olsa da büyük ölçüde ihracata dayalı ülke ekonomisi, tarım ürünlerindeki fiyat düşüşünden önemli ölçüde zarar görmüştür. ${ }^{4}$ Buhranın olumsuz etkilerinden kurtulabilmek için dünyadaki birçok kapitalist ülke himayeci ve kapalı ekonomi politikaları izleyerek kendi iç kaynaklarına yönelirken, Türkiye'de de takip edilmek istenen liberal ekonomi politikası yerini devletçiliğe bırakmıştır. ${ }^{5}$

Ulusal ve uluslararası koşulların zorunlu sonucu olarak devletçilik, ilk kez 30 Temmuz 1930 yılında Başvekil İsmet İnönü'nün Sivas demiryolu açılışı münasebetiyle yaptığ konuşmada "mutedil devletçilik" olarak ortaya atılmış ve bu tarihten sonra Atatürk, 1931 yılı Ocak ayında İzmir'de yaptığı konuşmasında devletçilik ilkesini şu sözlerle açıklamıştır:

"Fırkamızın takip ettiği program, bir istikametten tamamiyle demokratik, halkçı bir program olmakla beraber iktisadi noktai nazardan devletçidir... Halkımız tab'an devletçidir ki, her türlü ihtiyacı devletten talebetmek için kendisinde bir hak görüyor. Bu itibarla milletimiz tabayii ile firkamızın programında tamamiyle bir mutabakat vardır. $\mathrm{Bu}$ istikametten yürüyeceğiz. Ve muvaffak olacağımızda şüphe yoktur". ${ }^{6}$

Yapılan bu açıklamaları takiben, 1931 yılı Mayıs ayında yapılan Cumhuriyet Halk Fırkası (CHF) Üçüncü Büyük Kongre'sinde devletçilik ilkesi parti programına eklenmiş ve şu şekilde tanımlanmıştır:

"Ferdi mesayi ve faaliyeti esas tutmakla beraber, mümkün olduğu kadar az zaman içinde milleti refaha ve memleketi mamuriyete eriştirmek için milletin umumi ve yüksek menfaatlerinin icap ettigi işlerde -bilhassa iktisadi sahada- devleti alakadar etmek mühim esaslarımızdandır". ${ }^{7}$

\footnotetext{
${ }^{1}$ Kongrede yapılan konuşmalar ve alınan kararlar için bknz. Ayşe Afet İnan, İzmir İktisat Kongresi: 17 Şubat- 4 Mart 1923, Türk Tarih Kurumu Yayınları, Ankara 1989.

2 İsmail Türk, devletin iktisadi planda etkin rol almak istediğine vurgu yaparak izlenen iktisat politikasının karma model olduğunu belirtmiştir. İsmail Türk, “Atatürk ve Türk Mali Sistemi”, Atatürk Dönemi Ekonomi Politikasl ve Türkiye'nin Ekonomik Gelişmesi, Ankara Üniversitesi Siyasal Bilgiler Fakültesi Yayınları, Ankara 1982, s. 8.

${ }^{3}$ New York Borsası'nın çöküşü ile başlayan kriz, kısa sürede dünya geneline yayılmış, ticaretin durağanlaşması, fiyatların düşmesi, birçok banka ve şirkerin iflas etmesine, dolayısıyla büyük oranda işsizliğin ortaya çıkmasına neden olmuştur.

${ }^{4}$ Bernard Lewis, The Emergence of Modern Turkey, Oxford University Press, London 1968, s. 281.

5 Bilsay Kuruç, Belgelerle Türkiye İktisat Politikası (Cilt 1), Ankara Üniversitesi Siyasal Bilgiler Fakültesi Yayınları, Ankara 1988, s. XXXVIII; Avni Zarakolu, "1929/1930 Dünya Ekonomik Krizi Karşısında Türk Ekonomisi ve Alınan Krizle Mücadele Tedbirleri”, Atatürk Dönemi Ekonomi Politikası ve Türkiye'nin Ekonomik Gelişmesi, Ankara Üniversitesi Siyasal Bilgiler Fakültesi Yayınları, Ankara 1982, s. 90.

${ }^{6}$ Atatürk'ün Söylev ve Demeçleri (1919-1938), Atatürk Araştırma Merkezi, Ankara 2006, s. 390-391.

${ }^{7}$ Cumhuriyet Halk Fırkasının Ana Vasıfları, CHP Üçüncü Büyük Kongre Zabıtları, Ankara 1931, s. 30.
} 
1937 yılında ise ilke anayasada yer almıştır. Böylelikle devletçilik hemen herkesin kayıtsız şartsız kabul ettiği bir ilke haline gelmiştir. ${ }^{8}$ Devletçilik diğer beş ilke (cumhuriyetçilik, laiklik, halkçılık, inkılapçılık, milliyetçilik) ile kıyaslandığında üzerinde tam bir uzlaşmanın sağlanamadığı dolayısıyla en çok tartışılan ilke olmuştur. 1931 yılında CHF Genel Sekreteri olarak atanan Recep Peker, devletçiliği Büyük Buhran'ın zorunlu sonucu olarak görmekten ziyade, Türk devriminin başlangıcından itibaren parti uygulamalarının doğal bir sonucu olarak görmüştür. Peker gibi İnönü'de bu ilkeyi mevcut dünya koşullarının uygulamaya zorladığı bir ilke olarak değil, Türkiye'nin içinde bulunduğu durumun doğal bir yansıması olarak değerlendirmiştir. Gerek Peker ve gerekse İnönü devletçilik uygulamasını geçici bir iktisat politikası olarak görmenin aksine, halkın menfaati için üretimin bazı alanlarda kalıcı olarak devlet kontrolünde kalması gerektiğini düşünmüşlerdir. ${ }^{9}$ İnönü, Kadro dergisine yazmış olduğu makalede devletçiliği, "yıllarca süren ihmali telafi edebilecek, devleti iktisadi hayatta yıpratacak etkenlerden koruyabilecek ve dönemin koşullarına uyum sağlayabilmesine olanak verecek bir mudafaa vasıtası" olarak gördügünü ifade eder. ${ }^{10}$ Peker ve İnönü gibi bu iktisat politikasını kalıcı bir çözüm olarak görenlerin aksine, Ahmet Ağaoğlu ve Celal Bayar gibi devletçiliğin geçici bir çözüm olduğunu savunan ve "kişilerin yapamadığını devlet yapar" anlayışına sahip politikacılar da mevcuttu. ${ }^{11}$ Devletçiğin kapsamına dair bu farklı görüşlerin yanında dönemin milletvekillerinden Yakup Kadri Karaomanoğlu, bu ilkenin mecliste büyük bir çoğunluk tarafından ekonomik sistem olarak anlaşılmasından ziyade, "devlet taraftarı olmak" gibi siyasi bir anlam taşıdığını ifade eder. ${ }^{12}$ Sınırları tam olarak çizilmediği için devletçilik, farklı yorumlamalara açık bir ilke olmuş, gerek uygulandığı dönemde gerekse sonrasında birçok tartışmayı beraberinde getirmiş̧tir.

Türkiye'de devletçilik ilkesinin benimsenmesinin ardından, iki farklı politika aracı birlikte uygulanmış, bir yanda ülkede sanayinin gelişmesi için korumacı politikalar uygulanırken, diğer yanda sanayiler devlet eliyle kurulmuş ve özel sektör sanayi yatırımları yapmaya teşvik edilmiştir. ${ }^{13}$ Devletçi ekonomi politikası uygulanmasının yanı sıra, İsmet İnönü'nün 25 Nisan10 Mayıs 1932 tarihleri arasında Sovyetler Birliği ziyaretinin ardından 8 milyon dolarlık kredi yardımı alınmış ve Birinci Beş-Yıllık Kalkınma Planı hazırlıklarına başlanmıştır. Dönemin Ekonomi Bakanı Mustafa Şeref (Özkan) ve Sanayi Genel Müdürü Ahmet Şerif (Onay)'ın denetimi altındaki teknik kadro ile hazırlanan ilk beş yıllık kalkınma planı 1934 yılında yürürlüğe girmiş, yerli hammadde kullanılması, tüketim mallarının üretimine öncelik verilmesi ve yeni sanayi dallarının yerel kaynaklar kullanılarak kurulması hedeflenmiştir. ${ }^{14}$ Sovyetler Birliği'nden sonra, planlı ekonomiyi uygulayan ikinci ülke olan Türkiye'de, teknik ve mali yardımların bir sonucu olarak, Türk ekonomisinde kamu iktisadi teşebbüsleri olarak bilinen önemli kurumlar kurulmuştur. 1930'lu yıllarda kurulmuş olan Bakırköy, Ereğli ve Nazilli dokuma fabrikaları gibi kurumlar ile çeşitli sanayi dallarının gelişimine öncülük edilirken, Sümerbank, Etibank ve Denizcilik Bankası gibi kurumlar ile bu girişimlerin gelişimine finansal destek sağlanmıştır. Devletin iktisadi teşebbüsler aracılığıyla üretime katılması sayesinde madencilik üretimi, 1923-1931 yıllarında özel teşebbüs performanslarının aksine gelişmeye

\footnotetext{
${ }^{8}$ Temuçin Faik Ertan, Kadrocular ve Kadro Hareketi, T.C. Kültür Bakanlığı, Ankara 1994, s. 139.

9 İlhan Tekeli-Selim İlkin, Uygulamaya Geçerken Türkiye'de Devletçiliğin Oluşumu, Ortadoğu Teknik Üniversitesi, Ankara 1982, s. 103.

10 İsmet İnönü, "Fırkamızın Devletçilik Vasfi", Kadro, C. 2, S.22, Ekim 1933, s. 4-6.

${ }^{11}$ Tekeli-İlkin, age, s. 81. Feroz Ahmad, İttihatçılıktan Kemalizme, Kaynak Yayınları, İstanbul 1996, s. 172.

${ }^{12}$ Yakup Kadri Karaosmanoğlu, "Atatürkçülüğün Ekonomik ve Sosyal Yönü Semineri", İktisadi ve Ticari İlimler Akademisi, İstanbul 12-13 Ekim 1973, s.50.

${ }^{13}$ Tekeli-İlkin, age, s. 134.

14 İlhan Tekeli-Selim İlkin, Bir Cumhuriyet Öyküsü Kadrocuları ve Kadro'yu Anlamak, Tarih Vakfı Yayınları, İstanbul 2003, s. 187; Lewis, age, s. 285-286.
} 
başlamıştır. $^{15}$ 1932-1939 yılları arasında demiryolları, deniz hatları, liman ve iskele operasyonları tamamen millileştirilmiştir. ${ }^{16}$ Ancak bu dönemden sonra, İkinci Dünya Savaşı'nın olumsuz etkileri nedeniyle ekonomik durgunluk başlamış, İkinci Beş-Yıllık Kalkınma Planı 1938 'de yürürlüğe girmesine rağmen askeri harcamalar ve hammadde eksikliği nedeniyle zaman içerisinde verimliliğini yitirmiştir. ${ }^{17}$ Sonuç olarak, 1930 'lu yıllarda uygulanan devletçilik politikaları büyük ölçüde başarıya ulaşmış, takip eden dönemde ise iç ve dış koşulların etkisi ile devletçilik zaman içerisinde terk edilmiş ve yerini liberal ekonomi politikalarına bırakmıştır.

Devletçi ekonomi politikası izlenirken, devlet tarafından başlatılan uygulamaların başarıya ulaşabilmesi bakımından halkın da izlenen bu politikalar doğrultusunda yönlendirilmesi zaruri bir ihtiyaç olarak belirmiştir. Bu çalışmada, söz konusu ihtiyacın giderilmesi için kurulmuş olan Milli İktisat ve Tasarruf Cemiyeti incelenerek, Türkiye'nin iktisadi, siyasi ve sosyal açıdan bir arayış içinde olduğu 1930'lu yıllar üzerine yapılmış çalışmalara katkıda bulunulması hedeflenmektedir. Cemiyet, günümüzde "Tutum, Yatırım ve Türk Malları Haftası" ile sembolleşen iktisadi, sosyal ve siyasi bir eğilimin mimarı olmuştur. Devletin iktisadi politikalarına katkı sağlamanın yanında, halkın sosyo-kültürel gelişimi için de önemli faaliyetlerde bulunmuş olması, Cemiyeti Türk modernleşme sürecinin anlaşılması bakımından da önemli kılmaktadır. Türkiye'nin 1930'lu yıllarının nasıl şekillendiğinin anlaması bakımından önemli bir yere sahip olan cemiyet hakkında pek çok akademik çalışma yapılmıştır. Doğan Duman, Yaşar Semiz ve Asım Süreyya İloğlu tarafindan yapılan çalışmalar bu alanda yapılmış en kapsamlı çalışmalardır. ${ }^{18}$ Cemiyetin kuruluş süreci ve yaptığı faaliyetler bu çalışmalarda detaylı olarak ele alınmıştır. Bu çalışmada ise Milli İktisat ve Tasarruf Cemiyeti Althusser'in kavramlaştırdığı Devletin İdeolojik Aygıtları kavramlaştırması kapsamında ele alınırken cemiyetin egemen ideoloji ve bu ideolojiyi geliştiren devlet aygıtı ile olan ilişkisi üzerinde durulmuştur. Bahsedilen çalışmaların tamamında cemiyetin devlet aygıtı ile olan organik bağ tespit edilmesine karşın cemiyetin faaliyetlerinin bu ilişkiden ne şekilde etkilendiği, özellikle egemen ideolojinin üretilmesi ve yaygınlaştırılmasına ne şekilde katkı yaptı̆̆ 1 yeterince vurgulanmamıştır. İlhan Tekeli ve Selim İlkin, dönemin iktisadi gelişimini ele aldıkları çalışmalarında cemiyetin faaliyetlerinin dönemin siyasi gelişmelerinden bağımsız düşünülemeyeceğine işaret etmişlerdir. ${ }^{19} \mathrm{Bu}$ çalışmada cemiyetin faaliyetleri devletin ideolojik aygıtları kavramlaştırması ekseninde ele alınırken, dönemin siyasi koşulları ve egemen ideolojinin bu süreçte gelişimi, dönemin iktisadi koşulları ile birlikte analiz edilmiş, böylelikle farklı bir bakış açısıyla mevcut literatüre katkı yapılması hedeflenmiştir.

\section{Devletin İdeolojik Aygıtı Olarak Milli İktisat ve Tasarruf Cemiyeti}

Althusser'e göre devlet aygıtının temel fonksiyonu üretim ilişkilerinin yeniden üretimini sağlamaktır ve bu görevi yerine getirirken kullandığı iki temel araç vardır. Devletin bask1 aygıtları olarak; tanımladığı hükümet, ordu, polis, mahkemeler ve hapishaneler, yeniden üretim sürecini zorlayıcı tedbirler aracılığı ile sağlayan araçlardır. Devletin ideolojik aygitları olarak

\footnotetext{
15 "Birinci 5 Yıllık Endüstri Programının Tatbikatı", Ulusal Ekonomi ve Arttırma, C.5, S.9, Eylül 1936, s. 2-3; Ahmet Yücekök, Türkiye'de Parlamentonun Evrimi, Ankara Üniversitesi Siyasal Bilgiler Fakültesi Yayınları, Ankara 1983, s. 118.

${ }^{16}$ Korkut Boratav, 100 Soruda Türkiye'de Devletçilik, Gerçek Yayınları, İstanbul 1974, s. 158, 269.

${ }^{17}$ Korkut Boratav, Türkiye'de Devletçilik, İmge Kitabevi Yayınları, İstanbul 2005, s. 157; Lewis, age, s. 296.

${ }^{18}$ Doğan Duman, Milli İktisat ve Tasarruf Cemiyeti, (Dokuz Eylül Üniversitesi Atatürk İlkeleri ve İnkılap Tarihi Enstitüsü, Yayınlanmamış Yüksek Lisans Tezi), İzmir, 1990; Yaşar Semiz, 1929-1938 Döneminde Milli İktisat ve Tasarruf Cemiyeti, Selçuk Üniversitesi Sosyal Bilimler Enstitüsü, Yayınlanmamış Doktora Tezi), Konya, 1991; Asım Süreyya İloğlu, Türkiye Ekonomi Kurumunun Kuruluşu ve 1929-1973 Yılarındaki Çalışmalarına Toplu Bir Bakış, Türkiye Ekonomi Kurumu Yayınları, Ankara 1974.

19 İlhan Tekeli-Selim İlkin, 1929 Dünya Buhranında Türkiye'nin İktisadi Politika Arayışları, Ortodoğu Teknik Üniversitesi, Ankara 1977, s.81
} 
tanımladığı; aile, din, iletişim, eğitim ise devletin yeniden üretim sürecini ideoloji aracılığı ile yürüttüğ̈̈ araçlardır. ${ }^{20} \mathrm{Bu}$ aygıtların fonksiyonları ayrı olmakla birlikte, birbirlerini tamamlayarak aynı ortak gayenin işleyişini sağlamaktadırlar. Bununla birlikte ideoloji egemen bir rol oynamaktadır. Althusser, ideolojinin egemen rol oynamasının nedenini, ideolojinin bireyleri "kendi başlarına eyler kılması" olarak tanımlar. ${ }^{21}$ Bir başka ifade ile devletin baskı aygıtlarının koruyuculuğu ve desteği altında faaliyet gösteren ideolojik aygıtlar, bireyin üretim ilişkilerinin yeniden üretim sürecinde üzerlerine düşen görevleri rıza ile yerine getirerek kendi başına işleyişin sağlanmasına imkân tanımaktadır. Devletin baskı aygıtları ancak bu sürecin kesintiye uğradığı (kuralların ihlali, grev, lokavt) zamanlarda devreye girmektedir. ${ }^{22}$

Althusser, devletin ideolojik aygitlarının üretim ilişkilerinin yeniden üretimi sürecindeki fonksiyonunu ideolojinin niteliği üzerine yaptığı değerlendirme ile açıklamıştır. Marksist literatürün ideolojiyi pozitivist-tarihçi bir tez içerisinde negatif bir imgelemle tanımladığını belirten Althuser, kendi yaklaşımını, Marksist literatüre karşıt olarak, ideolojinin tarihsel olmadığ (öncesinin ve sonrasının olmadığı) iddiası üzerine inşa etmiş ve bu yaklaşımı pozitif bir yaklaşım olarak tanımlamıştır. ${ }^{23}$ Althuser'in ideolojiyi bu şekilde değerlendirmesinin sebebi, ideolojiyi "bireylerin gerçek varoluş koşullarıyla kurdukları hayali ilişkinin hayali bir temsili" olarak tanımlamasıdır. ${ }^{24} \mathrm{Bu}$ tanıma göre bireyler, doğalarının gereği olarak, din, aile, çevre gibi kurumlarla bir aidiyet tesis etme eğilimindedir ve her kurumun inanç ve pratiği ile bir ilişki tesis ederler. Bu sebeple ideoloji hayatın doğal bir parçasıdır ve rıza temeline dayanır. Başka bir ifade ile bireyler ideolojinin çağrısına rıza ile katılırlar. ${ }^{25}$ Devletler, farklı ideolojiler (din, aile, hukuk) arasındaki çatışmaları önleyen bir "egemen ideoloji" oluştururlar ve bireylerin bu ideolojiyle aidiyet ilişkisi kurmaları için farklı fonksiyonlara sahip ideolojik aygıtlardan faydalanırlar. ${ }^{26}$ Böylelikle bireyler egemen ideoloji ile bir ilişki tesis ettikten sonra onun çağrılarına rıza temelinde katılırlar ve devletin temel görevi olan üretim ilişkilerinin yeniden üretimi sürecini kendi başına işler bir hale getirirler.

Cumhuriyetin kurucu elitleri de üretim ilişkilerinin radikal bir şekilde değiştiği ulus inşa sürecinde ideolojinin bu fonksiyonundan etkin bir şekilde faydalanmışlar, devlet ideolojisini oluşturan Türk devriminin değerlerinin benimsenmesi, korunması ve yayılması gibi amaçlarla Althusser'in kavramlaştırdığı ideolojik aygıtları yoğun bir şekilde kullanmaya çalışmışlardır. Örneğin, standart eğitim kurumlarına ek olarak 1932 yılında açılmaya başlayan Halkevleri, halkın eğitimi için kültür merkezi olmanın yanı sıra, egemen ideolojinin halka benimsetilmesi bakımından da önemli bir misyonu yerine getirmiştir. 1929 ekonomik krizi, üretim ilişkilerinde radikal bir dönüşümü zorunlu kılarken, bu sürecin etkili bir şekilde işleyişi için yeni bir ideolojik aygıtın varlığı da gerekli görülmüştür. Bu ihtiyacı karşılamak için kurulan Milli İktisat ve Tasarruf Cemiyeti'nin üstlendiği görevin iktisadi ve ideolojik boyutlarının anlaşılabilmesi bakımından krizin ortaya çıkardığı ihtiyaçlara ve dönemin siyasal yapısına bakmak faydalı olacaktır.

1929 yılı Ekim ayında Amerika Birleşik Devletleri'nde başlayan ekonomik kriz, küresel bir boyut kazanırken, Türkiye'de krizin etkileri ilk olarak Türk Lirasının Sterlin karşısında değer kaybetmesi ile kendisini göstermiştir. Gerçek para değerlerinin borsa değerlerinin

\footnotetext{
${ }^{20}$ Louis Althusser, İdeoloji ve Devletin İdeolojik Aygıtlarl, Çev.: Alp Tümertekin, İletişim Yayınları, İstanbul 2000, s. 52-53.

${ }_{21}$ Age, s. 106.

${ }^{22}$ Age, s. 138-143.

${ }^{23}$ Age, s. 102-104.

${ }^{24}$ Age, s. 112.

${ }^{25}$ Age, s. 115-122.

${ }^{26}$ Age, s. 53.
} 
üstünde olması gibi yapısal nedenlerin yanında, bu değer kaybının önemli bir nedeni krizin kamuoyunda neden olduğu panik havası olmuştur. ${ }^{27}$ İsmet İnönü, Türk Lirasının yaşadığı değer kaybının nedenleri ve alınması gereken tedbirler hakkında 12 Aralık 1929 tarihinde yaptığ meclis konuşmasında, çeşitli çevreler tarafından yapılan spekülatif değerlendirmelerin bir panik havası yarattı̆̆ını belirtmiştir. Aynı konuşmada Başvekil'in üzerinde durduğu bir diğer husus, halkın tasarruf ilkelerine uymaması ve ithal mallara rağbet göstermesinin neden olduğu döviz sarfiyatı olmuştur. ${ }^{28}$ Sonuç itibariyle, ekonomik krizin neden olduğu değer kaybının önüne geçilebilmesi ve para politikasının daha iyi yönetilebilmesi için hükümet bir dizi tedbir almıştır. 1929 yılında çıkarılmış olan 1447 sayılı Menkul Kıymetler ve Kambiyo Borsaları kanunu kapsamında kambiyo ve nakit işlemlerimdeki spekülasyonları önleyebilmek için alınan tedbirlerin yetersiz kalması sebebi ile 20 Şubat 1930 tarihinde 1567 sayılı Türk Parasının Değerini Koruma kanunu çıkarılmıştır. Bunun yanında Bankalar konsorsiyumu ve ardından Merkez Bankasının kurulması gibi yeni yapılanmalara gidilmiştir.

Başvekilin konuşmasında belirttiği üzere alınan kurumsal tedbirlerin yanında halkın tüketim alışkanlıklarının değiştirilmesi de önemli bir ihtiyaç olarak belirmiştir. Şerif Mardin, toplumdaki iktisadi kültür eksikliğinin Osmanlı İmparatorluğu'nun çöküş sürecinin temel nedenlerinden biri olduğunu belirtir. ${ }^{29}$ Bu iktisadi kültür eksikliğini kendisini Büyük Buhran ile önemli ölçüde hissettirmiş ve iktisadi tedbirler hayati bir mesele olarak görülmüştür. $\mathrm{Bu}$ bağlamda, halkın doğru bilgilendirilerek spekülatif haberlerin neden olduğu olumsuz havayı değiştirmek, halkta tasarruf bilincini oluşturmak, yerli malı kullanımını arttırarak döviz sarfiyatını azaltmak ve böylece ithalat-ihracat dengesini sağlanmak açısından bir kurumun varlığı ihtiyaç olarak belirmiştir. İsmet İnönü bahsi geçen konuşmasında bu kuruma olan ihtiyacı ve hükümetin hedefini şu sözlerle ifade etmiştir:

"Eğer istihsalimiz kifayet etmiyorsa ve çalışkan vatandaş ekmekle kahve arasında muhayyer kalacaksa onun kahveyi tercih edip dermansız düşmemesi için gücümüz yettiği kadar kulağına bağıracağız. Güzel lavanta sürünmüş, ince ipekliler içinde Türk kızlarının cılız ve ciğeri çürümüş bir hale gelmesine muvafakat etmiyeceğiz... Aklı eren bütün vatandaşların şuurunu uyandırmak ve bu uğurda Devletin bütün kuvvetlerini harekete getirmek kat'i kararımızdır". ${ }^{30}$

Başvekilin Meclis'te yaptığı konuşmadan iki gün sonra devletin ideolojik bir aygıtı gibi işlev görecek olan Milli İktisat ve Tasarruf Cemiyeti kurulmuştur. Ankara Genel Merkez olmak üzere, yurdun dört bir yanında şubeler açılması planlanan cemiyetin nizamnamesinde belirtilen amac1, halkı israfla mücadeleye, hesaplı ve tutumlu yaşamaya ve tasarrufa alıştırmak, yerel ürünleri tanıtmak, sevdirmek ve kullanımını teşvik etmek, yerli malı ürünlerin üretimini arttırarak bu ürünlerin kalitesini yabancı mallar seviyesine getirmek ve fiyatlarını ucuzlatmaya çalışmaktır. Bir diğer amacı ise, yerli malların sürümünü arttırmak suretiyle milletin iyi yaşamasını temin etmektir. ${ }^{31}$ Mustafa Kemal'in Onursal Başkan olduğu Cemiyete, Meclis Başkanı Kazım Özalp Başkanlık etmiş, Genel Sekreterliğe ise dönemin İzmir Milletvekili Mustafa Rahmi Köken getirilmiştir. Milletvekillerinin tamamı üye olarak tescil edilmekle birlikte, yerli malı ürünler kullanmayı tercih etmek ve hükmü geçen kişilere de kullandırtmayı

\footnotetext{
27 İlhan Tekeli-Selim İlkin, 1929 Dünya Buhranında Türkiye'nin İktisadi Politika Arayışları, Ortodoğu Teknik Üniversitesi, Ankara 1977, s.81.

${ }^{28}$ İsmet İnönü, Türkiye Büyü̈ Millet Meclisi Zabıt Ceridesi (3. Dönem), Cilt: 1, Ankara 19 Aralık 1929, s. 30-36.

${ }^{29}$ Şerif Mardin, Türkiye'de Toplum ve Siyaset, İletişim Yayınları, İstanbul 1990, s. 148.

30 İsmet İnönü, Türkiye Büyük Millet Meclisi Zabıt Ceridesi (3. Dönem), Cilt: 1, Ankara 19 Aralık 1929, s. 33.

${ }^{31}$ Milli Iktisat ve Tasarruf Cemiyeti Nizamnamesi. Milli İktisat ve Tasarruf Cemiyeti, Ankara 1929.
} 
taahhüt etmek üye olabilmek için gerekli ve yeterli kriterler olarak belirlenmiştir. ${ }^{32}$ Açıldığ 1 yıldan itibaren kısa sürede büyük gelişme gösteren Cemiyetin 21 Nisan 1931 yılında yapılan Kongresi'nde yurt genelinde 171 şubesi olduğu belirtilmiş, ${ }^{33}$ ilerleyen yıllarda da gelişimini sürdürerek, il ve ilçelere yayılmış 273 şubeli geniş bir organizasyon ağ 1 oluşturulmuştur.

Athusser devletin ideolojik aygıtlarının daha çok özel kuruluşlar olarak faaliyet gösterdiğinin altını çizer. ${ }^{34}$ Milli İktisat ve Tasarruf Cemiyeti de her ne kadar devletin teşviki olsa da kamu yararına çalışan cemiyet niteliğinde özel bir kurum olarak kurulmuştur. ${ }^{35}$ Özel bir kurum olarak teşkil edilmesinin temel nedeni hükümetin yabancı malların protesto edilmesini teşvik eden bir politika izlediği izlenimi vermek istememesidir. Çünkü o dönemde devlet, Ford gibi yabancı otomotiv firmalarının yatırımlarını ülkeye çekebilmek için yoğun çaba harcamaktadır. ${ }^{36}$ Başvekil İnönü Mecliste yaptığı konuşmasında, yerel ürünlerin kullanılması yönünde propaganda yapılması durumunda dışarıdan gelebilecek tepkileri önemsendiğini şu sözlerle ortaya koymuştur:

"Nazik bir mevzuun bütün taraflarını anlatmış olmak için sözlerimde mukalevâtın itibarını sarsacak ve vatandaşlara harici mallara karşı cebri ve telkinî boykot ilan edecek bir mana yoktur. Böyle teşebbüslere şimdiye kadar olduğu gibi bundan sonra da müsaade etmiyeceğiz. Bilinmelidir ki milletlerin münasebetlerini tanzim eden muahedeler, milletler arasında alışveriş temin ettiği için milli kazancı da temin edecek başlıca çaredir. Devletin ittihaz ettiği tedbirleri medeni bir devletin hukuku dahilinde bulunan tedbirlerden alıyoruz". ${ }^{37}$

Zaman içinde bazı değişikliklere uğrayan Cemiyetin ismi, 1935 yılında Mustafa Kemal'in talebi üzerine "Ulusal Ekonomi ve Arttırma Kurumu" olarak değiştirilmiştir. 1955 yılına gelindiğinde ise Cemiyet, 1939 yllında kurulmuş olan "Türk İktisat Cemiyeti" ile birleşerek "Türkiye Ekonomi Kurumu" olmuş ve varlığını bilimsel faaliyetler yürüten özel bir kuruluş olarak günümüze kadar sürdürmüştür. ${ }^{38}$

Cemiyet halkın iktisat kültürünün geliştirilmesi ve tüketim alışkanlıklarının değiştirilmesi görevinin yanında yukarıda bahsedildiği üzere devletçilik politikası ile değişen üretim ilişkilerinin dönüşümü sürecinin yönlendirilmesi konusunda da öncü bir rol üstlenmeye çalışmıştır. Cemiyet, devletin ideolojik bir aygıtı olarak işlev gördüğü için hükümetin iktisadi politikaları ile tam bir uyum içerisinde çalışmalar yapmış, halkın bu politikalara adapte

\footnotetext{
${ }^{32}$ Vedat Nedim Tör, Yıllar Böyle Geçti, Yapı Kredi Yayınları, İstanbul 1999, s. 15. Cumhuriyet Halk Partisi genel merkezi tarafından il idare heyetlerine gönderilen talimatta cemiyete üye kaydının arttırılması maksadı ile çalışma yürütülmesi talimatı verilmiş, böylelikle cemiyetin ülkenin tamamında etkin olması hedeflenmiştir. DAB: Milli İktisat ve Tasarruf Cemiyeti'ne Üye Kaydına Yardım Edilmesi, 490.1.0.0/1.3.22, 20.02. 1930.

${ }^{33}$ Asım Süreyya İloğlu, Türkiye Ekonomi Kurumunun Kuruluşu ve 1929-1973 Yılarındaki Çalışmalarına Toplu Bir Baklş, Türkiye Ekonomi Kurumu Yayınları, Ankara 1974, s. 21-44.

${ }^{34}$ Althusser, age, s. 52-53.

${ }^{35}$ Cemiyet 1934 senesinde Kamu yararına faaliyet gösteren dernek statüsüne alınarak bazı vergi muafiyetleri sağlanmış böylelikle faaliyetlerini daha etkin yürütmesine katkı sağlanmıştır. Bknz. Devlet Arşivleri Başkanlığ (DAB), Milli İktisat ve Tasarruf Cemiyetinin Kamu Yararına Dernek Sayllmast, 30.18.1.2/42.2.15, 13.01.1934. Bunun yanında devlete ait taşınmazların kullanılmasına izin verilmesi gibi ilave desteklerde bulunulmuştur. Bknz. DAB: Milli Iktisat ve Tasarruf Cemiyetine 2. Vakıf Apartmanındaki Yazıhanenin Kiralanması, 30.18.1.2/40.77.5, 05.11.1933. Ayrıca, Cumhuriyet Halk Fırkası tarafından cemiyetin bütün faaliyetlerine destek verileceği belirtilmiştir. Bknz. DAB: Milli İktisat ve Tasarruf Cemiyetinin Çalışmalarına Yardımcı Olunması, 490.1.0.0/2.7.18, 15.10.1931.

36 İlhan Tekeli-Selim İlkin, 1929 Dünya Buhranında Türkiye'nin İktisadi Politika Arayışları, Ortodoğu Teknik Üniversitesi, Ankara 1977, s. 76-77. Türkiye ile Amerika Ford Motor Şirketi arasında akdedilen mukavelenin tasdikine dair kanun maddesi görüşemleri için bknz. Bilsay Kuruç, Belgelerle Türkiye İktisat Politikası (Cilt 1), Ankara Üniversitesi Siyasal Bilgiler Fakültesi Yayınları, Ankara 1988, s. 11.

${ }^{37}$ İsmet İnönü, Türkiye Büyük Millet Meclisi Zabit Ceridesi (3. Dönem), Cilt: 1, Ankara, 19 Aralık 1929, s. 33.

${ }^{38}$ İloğlu, age, s. 67- 106; http://www.tek.org.tr/tarihce.php (E.T. 15.02.2019).
} 
olabilmesini sağlayabilmek için propaganda, eğitim ve koordinasyon çalışmaları yürütmüştür. A ğırlıklı olarak yerli malların tanıtımı, propagandasının yapılması ve okul çağındaki çocukların erken yaşlarından itibaren tasarruf yapma ve yerli malı kullanmaları konularında bilinçlenmeleri ve eğitilmeleri amacıyla faaliyet göstermiş ve kullandığı araçlar da bu niteliğine uygun olmuştur. Yanı sıra, mümkün olduğu kadar çok insana ulaşabilmek için ülke çapında konferanslar düzenlemiş, radyo programları yapmış, afiş, poster ve broşürler gibi yazılı ve görsel materyaller ile farkındalık yaratmaya çalışmıştır. Sanayicileri ve ziraat ile uğraşan kesimlerin daha kaliteli ve ucuz üretim yapmalarını sağlamak için Sanayi ve Tarım Kongreleri düzenlenmiştir. $\mathrm{Bu}$ kongrelerin yanı sıra yerli üreticilerin mallarının tanıtılması amacıyla yurt içinde sergiler düzenlemiş ve yurt dışında fuarlara katılmıştır. Bunların yanı sıra, faaliyetlerinin süreklilik arz etmesi bakımından İktisat ve Tasarruf isimli dergiyi aylık olarak yayınlamıştır. Dahası, "Yurdunu Tanı! Yurdunu Sev!" başlığı adı altında bir dizi kitap yayını yapmıştır. Bu yayınlar içerisinde Şevket Süreyya (Aydemir) tarafından kaleme alınan, "Cihan İktisadiyatında Türkiye" (1931), "Mektep Kooperatifçiliği ve Tasarruf Terbiyesi" (1932), "Ege Günü" (1933), "Orta Yayla" (1937) ve "Halk İçin İktisat Bilgisi" (1938) gibi kitaplar ${ }^{39}$ ve diğer tüm faaliyetler hem dönemin ruhunun hem de Cemiyetin devlet ile halkı bütünleşme çabalarına nasıl aracılık ettiğinin anlaşılması bakımından önem arz etmektedir.

Cemiyet, faaliyetlerini egemen ideoloji ekseninde yürütmekle birlikte egemen ideolojinin topluma benimsetilmesi doğrultusunda da görev üstlenmiştir. Diğer bir ifade ile cemiyet bir yandan üretim ilişkilerinin yeniden düzenlenmesinde sürekliliği sağlamak için egemen ideolojinin gücünden faydalanırken, diğer yandan egemen ideolojinin gücünün arttırılması yönünde faaliyet göstermiştir. Bunun temel nedeni, Türk devrimi ilkeleri ekseninde şekillenmiş olan Cumhuriyet ideolojisinin toplumda kök salması konusunda problem yaşanıyor olmasıdır. Ekonomik durgunluğun yanı sıra devrim ilkelerinin getirdiği değişim, toplumum bazı kesimlerince benimsenmemiş ve gerilimlere neden olmuştur. Bu gerilimlerin üstesinden gelebilmek adına Mustafa Kemal, Türk Devrimi'ne olan bağlılı̆̆ına güvendiği arkadaşı Fethi Okyar'dan siyasi parti kurmasını istemiş ve kurulacak partinin misyonu güdümlü muhalefet olarak tasarlanmıştır. İki partili sistem ile halkın taleplerinin Türk Devrimi'nin ana istikametini değiştirmeden meclise taşınması sağlanırken, siyasi gerilimin düşürülmesi ve izlenecek iktisadi ve siyasi program üzerinde bir uzlaşma sağlanması öngörülmüştür. Bu doğrultuda Serbest Cumhuriyet Fırkası ${ }^{40} 12$ Ağustos 1930 tarihinde kurulmuştur. Parti kuruluşundan itibaren kısa sürede büyük bir destek görmeye başlamış, toplumun partiye göstermiş olduğu yoğun ilgi gerek iktidar bloğunu gerekse Fethi Okyar'ı tedirgin etmiştir. ${ }^{41}$ Mevcut gelişmelerin kendisi ile Atatürk karşı karşıya getireceğini düşünen Fethi Okyar kuruluşundan birkaç ay sonra partiyi 17 Kasım 1930 tarihinde kapatmış ve böylece ülke, parti ve devlet bütünleşmesinin gerçekleşeceği tek parti sistemi ile yönetilmeye devam etmiştir. ${ }^{42}$

Serbest Cumhuriyet Fırkası denemesinden kısa bir süre sonra toplumdaki hoşnutsuzluk kendisini İzmir'in Menemen ilçesinde meydana gelen irticai bir ayaklanma ile göstermiştir. Nakşibendi tarikatına bağlı Derviş Mehmet isimli şeyh liderliğinde toplanan grup, Şeriatın ve halifeliğin yeniden tesis edilmesi talebiyle ayaklanma başlatmışlardır. Olaylara müdahalede bulunan birliğin başında bulunan Kubilay isimli yedek subay ayaklananlar tarafından vahşice

\footnotetext{
${ }^{39} \mathrm{Bu}$ eserlerin detaylı analizi için bknz. Nurdan Güven-Toker, A Biographical Study of a Utopian Intellectual: Şevket Süreyya Aydemir, (Yeditepe Üniversitesi Sosyal Bilimler Enstitüsü, Yayımlanmamış Doktora Tezi), İstanbul 2019.

${ }^{40}$ Partinin diğer kurucuları Nuri Conker, Ahmet Ağaoğlu, Mehmet Emin Yurdakul, Reşit Galip, Süreyya İlmen, Refik İsmail Kakmakçı, Tahsin Uzer, ve Nakiyeddin Yücekök'dür.

${ }^{41}$ Feroz Ahmad, The Quest for Identity, Oneworld Publications, Oxford 2003, s. 59-60; Kemal Karpat, Türk Demokrasi Tarihi, Timaş Yayınları, İstanbul 2010, s. 151-153.

${ }^{42}$ Yücekök, age, s. 113.
} 
öldürülmüştür. Bu olayların Anadolu'nun az gelişmiş bölgelerinde değil de İzmir gibi ülkenin geçirdiği dönüşüme ayak uydurması bakımından örnek olması beklenen bir şehirde meydana gelmiş olması iktidar üzerinde sarsıcı bir etki yapmıştır. Genel Kurmay Başkanlığı'na gönderdiği başsağlığı telgrafında Atatürk hissettiği hayal kırıklığını "Mürtecilerin gösterdiği vahşet karşısında Menemen'deki ahaliden bazılarının alkışla tasvipkar bulunmalarının bütün cumhuriyetçi ve vatanperverler için utanılacak bir hadise" olduğu sözleriyle ifade etmiștir. ${ }^{43}$ Feroz Ahmad'e göre, Menemen olayı devrimlerin ancak halka izah edildiği ve onaylarının alındığı takdirde toplumda kök salabileceği gerçeğinin ortaya koymuştur. ${ }^{44}$ Bu bağlamda, Türk Ocakları tarafından düzenlenen bir konferans dizisi ile bir araya gelen dönemin aydınları ülkedeki bu soruna cevap aramaya çalışmışlardır. ${ }^{45} \mathrm{Bu}$ konferanslar zincirine katılan aydınlardan Şevket Süreyya (Aydemir), "İnkılâbın İdeolojisi" başlıklı sunumunda, Türk İnkılabının sistemleştirilerek halka anlatılması ve devletçi ekonomik model eşliğinde bir kalkınma programı izlenmesi gerektiğini belirtmiştir.

Cemiyet, siyasal gelişmelerin ortaya koyduğu bu gerçeklik karşısında Türk Devrim değerlerinin halk tarafından benimsenmesi için de çaba harcamıştır. Örneğin, Cemiyetin Ankara'da açtığı sergi salonlarından biri "Lozandan Önce, Lozandan Sonra" olarak adlandırılmıştır. Türk Devrimi ve Cumhuriyetin kazanımlarını halka anlatmak amacıyla rakam, tablo ve grafiklerden yararlanılarak, 1930'lu yıllara kadar katedilen gelişmeler sunulmuştur. Bu sergide, İmparatorluk döneminde devletin iktisadi ve siyasi alanda yarı müstemleke haline getirildiği, fakat Cumhuriyet Türkiyesi'nin ekonomik ve siyasi alanda tam bağımsız bir ülke olduğu ifade edilmiştir. ${ }^{46}$ Cemiyetin yayın organı olan İktisat ve Tasarruf dergisinde Kadri Kemal tarafından kaleme alınan makalede, Osmanlı'nın yarı müstemleke haline gelmesinin temel nedeni olarak saltanat rejimi gösterilmiş, devletin elde ettiği sınırlı gelirlerin Sultanların keyiflerine ve uygulanan yanlış siyasetlerin sonucu ardı arkası gelmeyen harplere harcandığı vurgulanmıştır. Lozan Antlaşması ile milletin iktisadi ve siyasi bağımsızlığını kazandığ belirten Kadri Kemal, halktan yeni rejime sahip çıkması istemiştir. ${ }^{47}$ Cemiyet içerisinde faaliyet gösteren önemli isimlerin aynı zamanda Kadro Dergisi'nin ${ }^{48}$ kurucu yazarları arasında yer almış olmaları, Cemiyetin ideolojik yöneliminin daha iyi anlaşılması bakımından önem arz etmektedir. 1932 yılında yayın hayatına başlayan Kadro Dergisi, Türk inkılâbının ideolojisini oluşturmak ve devrim heyecanını canlı tutarak, devletçi iktisat politikası ekseninde kalkınma programı sunmak amacıyla faaliyet gösteren, gerek yayın döneminde gerekse sonraki yıllarda çok ses getiren bir dergi olmuştur. Kadro Dergisi'nin kurucu kadrosunda yer alan, Cemiyetin Müşavir Müdürü ve yayın organının Yazı İşleri Müdürü olan Vedat Nedim Tör, Leipzig Sergisinin açılışı münasebeti ile yaptığı konuşma, cemiyetin ideolojik misyonunun anlaşılması bakımından iyi bir örnek oluşturmuştur:

"Evvela yeni Türkiye ile eski Türkiye arasında siyasi ve içtimai hiçbir benzerliğin bulunmadığını tespit edelim. Nasıl ki zeytinyağı ile su biribirlerine kaynaşamaz ise yeni Türkiye ile Eski Türkiyeyi de birbirlerile birleştirmenin imkanı yoktur. Hasta adam öldü. Şimdi

\footnotetext{
${ }^{43}$ Feroz Ahmad, The Making of Modern Turkey. Routledge, New York 2003, s. 60.

${ }^{44}$ Feroz Ahmad, The Quest for Identity, Oneworld Publications, Oxford 2003, s. 88.

${ }^{45}$ Mehmet Şevki Toker, An Islamist Intellectual in Turkish Political Life: An Intellectual and Political Biography of Necip Fazıl Kısakürek (1904-1983), (Yeditepe Üniversitesi Sosyal Bilimler Enstitüsü, Yayımlanmamış Doktora Tezi), İstanbul 2018, s. 46.

46 "Lozandan Önce, Lozandan Sonra", Iktisat ve Tasarruf, C. 3, S.12-13, Aralık 1934, s. 7-8.

${ }^{47}$ Kadri Kemal, "Lozandan Önceki ve Sonraki Türkiye", Iktisat ve Tasarruf, C. 4, S. 5, Mayıs 1935, s. 2-4.

${ }^{48}$ Dergi 1932 Ocak-1934 Aralık dönemlerinde toplam 36 sayı olarak yayınlanmıștır. Kurucuları Kadrocular olarak bilinen Şevket Süreyya Aydemir (1897-1976), Vedat Nedim Tör (1897-1985), İsmail Hüsrev Tokin (1902-1992), Burhan Asaf Belge (1899-1967), Yakup Kadri Karaosmanoglu (1889-1974), ve Mehmet Şevki Yazman (18961974)'dır.
}

\section{History Studies}


arada bir uçurum vardır. Bir çöküş ve yaratılış vardır... Kurunu Vustai ve Asyai bir sultan ve halife devletinden modern ve lâyık bir devlet çıtı. Haremi ve fesi ile medeni dünya için bir garibeler diyarı olan eski Türkiyeden hâlâ hürriyet ve istiklallerini kazanmamıș yüzmilyonlar için bir istiklal timsali doğdu. İşte biz bu yeni Türkiyeyi milli kahramanımıza Mustafa Kemale borçluyuz". ${ }^{49}$

Cemiyet, bir yandan Türk Devrim ilkelerinin halka benimsetilmesi yönünde faaliyet gösterirken, diğer yandan kendi faaliyetlerinin etkisini arttırmak için devletin ideolojisinden faydalanmıştır. Bu bağlamda Cemiyetin yayın organı İktisat ve Tasarruf dergisinin ilk sayısında, "İlk Hedef Akdenizdi. İkinci Hedef: İktisat" sloganı ile Cemiyetin önderlik ettiği hareketin milli mücadelenin bir devamı olduğu vurgulanmaktayd. ${ }^{50}$ Üretim ilişkilerinin yeniden tanımlandığı 1930'lu yıllarda, Cemiyetin devletin ideolojisi ile kurduğu ilişkinin söylem ve pratiğe nasıl yansıdı ğı, yürüttüğü faaliyetler incelenirken açıklanmaya çalışılacaktır. Bu bağlamda, Cemiyetin devletin bir ideolojik aygıtı olarak yürüttüğü faaliyetleri, hedef ve kapsamları bakımından iki ayrı başlık altında incelemek mümkündür. Bu amaçla, ilk olarak Cemiyetin halk kitlelerine yönelik faaliyetleri ele alınırken, ikinci olarak üreticilere yönelik faaliyetleri incelenecektir.

\section{Cemiyetin Halka Yönelik Faaliyetleri}

Nizamnamesinde belirtildiği üzere, cemiyetin öncelikli hedefi halkın tüketim alışkanlıklarının değiştirilmesiydi. Bu bağlamda, halktan tüketim harcamalarını (özellikle lüks tüketim mallarında) kısarak birikim yapmaları ve ithal malları yerine yerli üretimin tercih edilmesi talep edilmekteydi. Böylelikle, ithalattan kaynaklanan ticaret dengesi açığ 1 azaltılabilecek ve döviz sarfiyatı kontrol altında tutularak Türk parasının değeri korunabilecekti.

$\mathrm{Bu}$ hedefler doğrultusunda cemiyetin en önemli faaliyeti, her yıl Aralık ayının 12. gününden başlayarak bir haftalık sürenin Tasarruf ve Yerli Malı Haftası ${ }^{51}$ olarak kutlanmasını sağlamak olmuştur. Böylelikle, cemiyet, devlet yetkililerinin arzu ettiği gibi ülke çapında bir seferberlik atmosferinin oluşmasını sağlamıştır. Başvekilin yanı sıra devletin önde gelen kişilerinin katıldığ 1 tören ile kutlanmaya başlanan Tasarruf ve Yerli Malı Haftası kapsamında okullarda özel programlar düzenlenmiş, halkın katıldığ 1 büyük toplantı ve mitingler organize edilmiş ve yurdun farklı yerlerinde çeşitli sergiler açılmıştır. Ülke genelinde ilgi uyandırmak için cemiyetin Ankara'da bulunan Genel Merkezi, diğer şehirlerde bulunan şubeleri aracılığıyla dağıtılması için altmış bin afiş bastırmıştır. Bu afişlerde "Yerli Malı Türkün Malı, Türk Malı Kullanmalı", "Az az da Olsa, Para Biriktirmeye Alış", "Ey Vatandaş! Tasarruf et ve Yerli Malı Kullan" gibi sloganlar ile halka hitap edilmiştir. ${ }^{52}$ Türkiye'nin ilk ekonomik festivali olan Tasarruf ve Yerli Malı haftası oldukça ilgi görmüş, bu haftayı organize eden kişilerden biri olan Vedat Nedim, daha önce ülke çapında bu kadar ilgi ve heyecan ile karşılanan bir ulusal kutlama olmadığını belirtmiştir. ${ }^{53}$ Dönemin gazete ve dergileri de bu hafta kapsamında özel yayınlar yapmıştır. Örneğin, Milliyet gazetesi "Vatandaş! Tasarruf ve yerli malı haftası başladı. Bu hafta bütün yiyeceğini, içeceğini, giyeceğini, yerli malından al. Yerli malı satmayan dükkandan

\footnotetext{
49 "Leipzig Sergisinde Türk Sesi", Kadro, S. 3, Mart 1932, s. 38-39.

50 “İlk Hedef Akdenizdi. İkinci Hedef: İktisat", İktisat ve Tasarruf, C. 1, S.1, Aralık 1931, s. 2

${ }^{51} 1940$ 'lı yıllarda haftanın adı kısaltılmış ve Yerli Mallar Haftası olarak kullanılmıştır. 1950 yılından itibaren ise "Ekonomi ve Yerli Mallar Haftası" adı ile faaliyetlerine devam etmiştir. Bknz. Tokgöz, Erdinç, Dünden Bugüne Türkiye Ekonomi Kurumu, İmaj Yayınevi, Ankara 2004, s. 20.

${ }^{52}$ Tokgöz, age, s. 21.

${ }^{53}$ Tör, age, s. 16.
} 
alışveriş etme" manşeti ile kamuoyu oluşturmaya çalışmıştır. ${ }^{54}$ Kadro Dergisi de 1932 Ocak ayında çıkardığı ilk sayısında Cemiyet faaliyetlerini desteklemiş, bu haftanın "milletin şuurunu ve hareket kabiliyetini görmek ve göstermek için canlı bir vesile" olduğunu belirterek, haftayı "Milli İktisat Seferberliği" olarak nitelendirmiştir. ${ }^{55}$ Yapılan kutlamaların toplumda yarattığı etkinin önemli göstergelerinden birisi, bankalarda açılan tasarruf hesaplarının sayılarındaki artış olmuştur. İş Bankası Genel Müdürlüğü tarafindan 1932 yılında sunulan bir raporda, Tasarruf ve Yerli Malı haftası içinde açılan tasarruf hesabı sayısını 629 olarak ifade etmiş, müteakip üç hafta içerisinde ise bu sayının yarıya yakın düştüğünü belirtilmiştir. ${ }^{56}$

Türkiye'de olduğu gibi Tasarruf ve Yerli Malı haftası, Birinci Dünya Savaşı sonrası dönemde devletin ihtiyaç duyduğu iktisadi birikimi sağlayabilmek için dünyanın pek çok ülkesinde başvurulan bir yöntem olmuştur. Bu bağlamda, İsviçre'de, her yıl yerli ürünleri halka tanıtmak ve kullanımını artırmak için "İsviçre Haftası" düzenlenmiştir. Almanya, Avusturya, Fransa, Macaristan, Hollanda, Sırbistan ve Bulgaristan gibi ülkelerde de benzer şekilde "ulusal ürünler haftası" kutlamaları yapılmıştır. Yine İtalya'nın birçok şehrinde uygulanan "Üzüm Günü" kutlamaları yerli ürünlerin tanıtımı konusunda Avrupa genelinde düzenlenen organizasyonların önemli örneklerinden biri olmuştur. ${ }^{57}$ Tasarruf yapmanın önemine değinmek üzere Şevket Süreyya (Aydemir), Birinci Dünya Savaşı öncesinde tasarrufun kişisel ve aileyi ilgilendiren bir mesele olduğunu fakat savaş sonrasında devletlerin artık bu meseleye daha fazla ulusal kalkınma odaklı bakmaya başladıklarını ifade etmiştir. Bu durumu gelişmiş ülkeleri örnek vererek açılayan Süreyya, savaş sonrası Amerika Birleşik Devletleri'nde tasarruf propagandası yapılarak 1919-1920 öğretim yılı arasında ilkokullarda 2.800.000 dolar biriktirildiğini belirtmiştir. ${ }^{58}$

Cemiyet, bu hafta ile oluşturulan seferberlik ruhunun tüm yıl canlı tutulabilmesi için yılın

Volume 11

Issue 2

A tribute to

Prof. Dr.

Mehmet Ali

ÜNAL

April

2019

geri kalan zamanlarında da konferanslar ve sergiler düzenlemeye devam etmiştir. Bu doğrultuda kullanılan en etkili araç İktisat ve Tasarruf dergisi olmuştur. Yirmi bin nüsha olarak basılan dergi, halk tarafindan kolaylıkla anlaşılabilecek üslup ile yazılmanın yanında basit ve çarpıcı sloganlarla halka hitap etmiştir. İnsanları tasarruf yapmaya ve yerli malı kullanmaya teşvik ederken, tasarruf sağlayabilmek için günlük hayatta uygulanabilecek pratik bilgiler içeren derginin yayın politikası incelendiğinde ağırlıklı olarak kentli orta sınıfa hitap ettiği söylenebilir. ${ }^{59}$ Dikkat çeken bir diğer husus ise derginin hedef kitle olarak çoğunlukla kadınları seçmiş olmasıdır. Dönemin kadın imgeleminin genel olarak çalışmayan ev kadınları olduğu görülmektedir. Sabiha Faik, dergide kaleme aldığı yazısında, kadınların tasarruf seferberliği içindeki yerini "erkek saçar kadın toplar" sözleri ile ifade etmiş ve tasarruf seferberliğinde en önemli sorumluluğun kadınlara düştüğünü belirtmiştir. ${ }^{60}$ Benzer şekilde, Başvekil İsmet İnönü de kadınların ev idaresinden sorumlu olduklarını vurgulayarak tasarruf seferberliğinde öncü bir role sahip olduklarını şu sözlerle vurgulamıştır:

"Arkadaşlarım! Vatandaşlar vazifelerini aramızda takdim ederken memleket için bu kadar hayati olan mevzuun bilhassa kadınlarımıza, kadın vatandaşlarımıza teveccüh ettiğini söylemeği bir borç bilirim. Eğer hanımlarımız, eğer kızlarımız ailede ve cemiyette yiyecek ve

\footnotetext{
54 "Vatandaş! Tasarruf ve yerli malı haftası başladı, Bu hafta bütün yiyeceğini, içeceğini, giyeceğini, yerli malından al. Yerli malı satmayan dükkandan alışveriş etme", Milliyet, 12 Aralık 1930.

55 "Tasarruf ve Yerli Malı Haftası", Kadro, Ocak 1932, s. 48.

56 "Mühim Bir Mukayese", İktisat ve Tasarruf, C.1, S. 9, Ağustos 1932, s. 6.

${ }^{57}$ İloğlu, age, s. 46

${ }^{58}$ Şevket Süreyya, "Cihan Biriktiriyor", Cumhuriyet, 12 Aralık 1930, s. 2.

59 1930'larda kentsel nüfuzun toplam nüfuza oranı yaklaşık olarak yüzde yirmi dörttür. Şevket Işık, "Türkiye'de Kentleşme ve Kentleşme Modelleri", Ege Coğrafya Dergisi, S. 14, 2005, s. 60.

${ }^{60}$ Sabiha Faik, "Milli İktisat ve Kadınlarımız", İktisat ve Tasarruf, C.1, S.6, Mayıs 1932, s. 6.
}

\section{History Studies}


giyeceği, mutlaka yerli malı almağı bir vazife ve deva olarak ellerine alırlarsa bu memleket iki seneye kalmadan yiyecek ve giyecek hususunda hariçten bir çöp bile almağa muhtaç kalmaz". ${ }^{61}$

Cemiyetin yürüttüğü faaliyetlerin toplumsal yansımaları bakımından dikkati çeken bir diğer husus, lüks tüketim alışkanlığını sürdürenlere yönelik bir kamuoyu baskısı oluşturulmasıdır. Özellikle toplumun zengin kesimine hitap edilen bu kampanyada kullanılan sloganlardan bazıları şu şekildedir: "Vatandaş! Yeni içtimai ahlak, yerli malı kullanmayı emrediyor, Kim ki yerli malı kullanmıyorsa, O, içtimai ahlaka karşı hareket ediyor demektir. Ona kem gözle bak!". "Yerli malı kullanmayanın düşmana cephane satan hainden farkı var mı?". ${ }^{62}$ Yayınları ile "mütevazı" bir hayat tarzını teşvik eden cemiyet, bu yolla, toplumda sosyal dengenin korunmasına katkı sağlanırken, gelir eşitsizliği nedeniyle ortaya çıkabilecek gerilimlerin önlenebileceğine inanmıştır. Buna mukabil, toplumun zengin kesimine yönelik bir önyargının geliştiğini söylemek de mümkündür. 1933 yılında Tasarruf ve Yerli Malı Haftası kapsamında Türk Talebe Birliği tarafından düzenlenen yürüyüşte şehir tiyatrolarında düzenlenen opera ve bale gösterilerinin toplumun zengin kesimine ait bir eğlence kültürü olduğu, Türk kültürü ile uyuşmadığ durdurulması yönünde konuşmalar yapılmış ve sloganlar atılmıştır. ${ }^{63}$

Halkın seferber edilebilmesi için milliyetçi söylemler Cemiyetin faaliyetlerinde sıklıkla kullanılmıştır. İsmet İnönü 1930 yılında ilk kez kutlanan Tasarruf ve Yerli Malı Haftası'nın Ankara Türk Ocakları'nda gerçekleşen açılışında yapmış olduğu konuşmada, tasarruf yapmanın ve ithal ürünler yerine yerli ürünleri tercih etmenin halkın tamamının yerine getirmesi gereken milli bir görev olduğunu vurgulamıştır. ${ }^{64}$ Kullanılan milliyetçi söylemin önemli bileşeni Türk devriminin beraberinde getirdiği kazanımlar olmuştur. Örneğin, Tasarruf ve Yerli Malı haftası halka şu ifadelerle tanıtılmıştır: "Bu haftayı milli istiklal hareketimizin zaferine borçluyuz. Saltanat Türkiyesinde, kapitülasyon Türkiyesinde, gümrük esareti Türkiyesinde, müstemleke Türkiyesinde böyle bir harekete cesaret etmenin imkanı yoktu. İktisadi istiklalimizin zaferini özleyen her Türk vatandaşı, gayelerimizin gönüllü propagandacısı olmak mecburiyetindedir" ${ }^{65}$ Benzer şekilde, İktisat ve Tasarruf dergisinde de yerli malı kullanmanın Cumhuriyetin ilanı ile beraber elde edilen bir özgürlük olduğu sıklıkla vurgulanmıştır. Osmanlı İmparatoluğu'nun kapitülasyonlar ve gümrük politikaları nedeniyle bağımsız olamadığı, bu sebeple milli sanayisini geliștiremediği, dolayısıyla da ithal malların piyasaya hakim olduğu, iktisadi ve siyasi olarak yarı sömürge konumunda olduğu için "her Türk, Türkiye malı kullanmalı" ilkesinin benimsenemeyeceği ifade edilmiştir. Dergide bu eksende kullanılan ilgi çelici bir sloganda "Eskiden yerli malı kullanmak ayıptı. Eskiden Türk'e, Türk demek de ayıptı"66 denilmektedir.

1930'lu yılların ilk yarısına gelindiğinde, Türk Parasının değerinin korunması önemli ölçüde başarılmıştır. İsmet İnönü, Tasarruf ve Yerli Malı haftası kapsamında yapmış olduğu açılış konuşmasında, bu başarının devlet ve halkın beraber ortak gaye doğrultusunda hareket etmesinin bir sonucu olduğunu belirtmiştir. ${ }^{67}$ Yapılan tasarruflar sayesinde elde edilen birikimin devletçi iktisat politikası ekseninde yürütülecek sanayileşme atılımları için bir

\footnotetext{
61 "Baş Vekilimizin Sözleri", İktisat ve Tasarruf, C.2, S. 2, Ocak 1933, s. 2.

62 "Vatandaş! Yeni İçtimai Ahlak, Yerli Malı Kullanmayı Emrediyor, Kim ki Yerli Malı Kullanmıyorsa, O, İçtimai Ahlaka Karşı Hareket Ediyor Demektir. Ona Kem Gözle Bak!", İktisat ve Tasarruf, C.1, S. 4, Mart 1932, s. 4.

${ }^{63}$ Duman, age, s. 109-110.

64 "İsmet ve Kazım Paşa'ların Muhim Nutukları", Cumhuriyet, 13 Aralık 1930, s. 1, 4.

65 "Tasarruf ve Yerli Malı Haftası", Iktisat ve Tasarruf, C. 1, S. 1, Ocak 1931, s. 1.

66 "Her Türk, Türkiye Malı Kullanmalı! Niçin?", Iktisat ve Tasarruf, C.1, S. 1, Ocak 1931, s. 4.

67 "Başvekil İsmet Pş. Hz. Tasarruf ve Yerli Malı Haftasını Bu Nutukla Açtı", İktisat ve Tasarruf, C.1, S. 2, Ocak 1932, s. 6.
}

\section{History Studies}


sermaye birikimine dönüştürülmesi bakımından önemli bir mesele olarak görülmüştür. 1930 yılında hazırlanan iktisat planında sanayileşme programının iç finansmana ve milli tasarrufa dayandırılması önerilmekteydi. ${ }^{68} \mathrm{Bu}$ sebeple, halkın elde ettiği birikimleri milli bankalara yatırması için yoğun bir kampanya yürütülmüştür. Kampanyada kullanılan sloganları bir kısmı şu şekildedir: "Evde saklanan para faiz getirmez. Tasarruf, bankada faizle üreyen paradır. Faiz sayesinde biriken para, zamanla, yatırılan paradan daha çok yekûn tutar. Banka tasarruf parasının kuluçkasıdır". ${ }^{69}$ "Tasarruf kumbarası olmayan bir aile, penceresiz bir odaya benzer". "Faiz getirmeyen para zarardır, bankada biriken para kâr getirir". ${ }^{70}$ Böylece, milli bankalara yatırılan birikimlerin devlet garantisi altında olduğu belirtilerek güven tesis edilmeye çalışılmış, dahası, Emlak ve Eytam Bankası, Sanayi ve Maadin Bankası, Ziraat Bankası ve İş Bankası gibi devlet bankalarının reklamlarına yer verilerek, bu bankalar yatırım için ön plana çıkarılmaya çalışılmıştır. Halkın yatırımlarını bu bankalarda değerlendirmeleri için "Iş̧ bankası kumbaraları, iktisat seferberliğinin cephanesidir. Vatandaş, İktisat harbinde silahlan". "Çocuğunun Tahsilini, saadetini düşünen baba hiç durmadan derhal Ziraat Bankasına gider ve bir kumbara alır" gibi sloganlarla yoğun bir kampanya yürütülmüştür. ${ }^{71}$ Yukarıda ifade edildiği gibi, Cemiyet bünyesinde yayınladığı kitaplarla da devletin tasarruf etme ve milli sermaye birikimi sağlama politikalarını desteklemiştir. Bu bağlamda Şevket Süreyya (Aydemir) tarafından kaleme alınan Mektep Kooperatifçiliği ve Tasarruf Terbiyesi isimli kitapta Süreyya, tasarrufun insanların gelecekteki yaşamları ile ilgili bireysel bir konu olduğunu, fakat eğer bu bireysel birikimler bankalar veya benzeri kuruluşlar aracılığıyla yapılırsa, tasarrufun ulusal sermayeye katkıda bulunacağını ve böylece tasarrufun sosyal bir mesele haline geleceğini ifade etmiş, aksi halde, yani, bireysel birikimlerin insanların kumbaralarında toplandığında, iktisadi bir reaksiyonculuk haline gelen milli sadakatsizliğe dönüşeceğini belirtmiştir. ${ }^{72}$

1938 yılında düzenlenen Tasarruf ve Yerli Malı haftasında dönemin Başbakanı Celal Bayar, para tasarrufu konusundaki dikkat ve çabanın giderek arttığını 1937'de 90 milyon tasarruf hesabının 1938'de 102 milyona ulaştığını belirtmiş ve Cemiyetin bu birikimin sağlanması yönünde öncü rol oynadığını belirtmiştir. ${ }^{73}$ Yapılan kampanyalara paralel olarak milli bankaların karları devamlı olarak artış sağlamış, buna mukabil yabancı bankaların kar oranları düşmüş̧ür. Ticaret hacminin küçülmesine rağmen Türk bankalarının bu başarısı elde edilen sermayenin sanayi yatırımlarına dönüştürülmesine önemli katkılar sağlamıştır. ${ }^{74}$

Bankalarda tasarruf hesabı açmanın yanı sıra, Cemiyetin vatandaşları yönlendirdiği diğer bir yatırım aracı devlet tahvilleri olmuştur. Bu bağlamda, Cemiyet dergi kanalı ile halkın devlet tahvilleri alarak hem daha fazla kar elde edeceği hem de memleketin imarına ve iktisadi yükselişine yardım edeceği bilgisini vermiştir. ${ }^{75}$ Türkiye'nin kapitalist bir devlet olmadığını belirten Yaşar Nabi, devletin kalkınması için halkın devlet yatırımlarına ortak olmasının zorunlu bir ihtiyaç olduğunu belirtmiştir. ${ }^{76} 1933$ yılında kutlanan Dördüncü Tasarruf ve Yerli

\footnotetext{
68 İlhan Tekeli-Selim İlkin, 1929 Dünya Buhranında Türkiye'nin İktisadi Politika Arayışları, Ortadoğu Teknik Üniversitesi, Ankara 1977, s. 130.

69 "Tasarruf Ne Demektir", Iktisat ve Tasarruf, C.1, S.1, Aralık 1931, s. 10.

70 "Paranı Evde Bırakma", Iktisat ve Tasarruf, C. 1, S. 2, Ocak 1932, s. 5.

71 "İş bankası kumbaraları, iktisat seferberliğinin cephanesidir. Vatandaş, İktisat harbinde silahlan", İktisat ve Tasarruf, C.1, S. 2, s. 16; "Çocuğunun Tahsilini, saadetini düşünen baba hiç durmadan derhal Ziraat Bankasına gider ve bir kumbara alır", Iktisat ve Tasarruf, C.1, S. 2, s. 15.

72 Şevket Süreyya, Mektep Kooperatifçiliği ve Tasarruf Terbiyesi, Milli İktisat ve Tasarruf Cemiyeti, Ankara 1932, s.14.

${ }_{73}^{73}$ Yunus Nadi, "İktisad Haftasının 4üncü Günü", Cumhuriyet, 16 Aralık 1938.

${ }^{74}$ Remzi Saka, Sermaye ve Kredi Hareketleri, Tecelli Matbaası, Ankara 1933, s. 29-40.

75 "Yurddaş: Kurduğumuz Fabrikalar ve Yaptığımız Demir Yollar Hep Ulusun Biriktirme Gücüne Dayanır, Bu Gücü Arttırmak Senin Elindedir", Ulusal Ekonomi ve Arttırma, C. 5, S. 7, Temmuz 1936, s. 3.

${ }^{76}$ Yaşar Nabi, "Ergani İstikrazı", İktisat ve Tasarruf, C. 3, S. 10, Eylül 1934, s. 4.
} 
Malı haftası dolayısıyla yaptı̆̆ı konuşmada Başvekil İnönü de halkın devlet yatırımlarına yönelmesinin yürütülmekte olan sanayileşme programı açısından önemli bir ihtiyaç olduğunu belirtmiştir. ${ }^{77} \mathrm{Bu}$ yatırım aracının güvenliğini vurgulamak için Cemiyet, yine egemen ideolojiden faydalanmıştır. Devlet istikraz senetleri hakkında yazılan bir makalede Cumhuriyet hükümetinin, saltanat devrinde yapılan ve harp masrafları için harcanan paraların mesuliyetini üstüne almaya mecbur olmamasına rağmen, sadece milletin devletine olan güvenini kırmamak için tasarruf yapanların haklarını koruduğu ve dahili istikraz senetlerinin kıymetini yükselttiği belirtilmiştir. $^{78}$

İkinci Dünya Savaşı'nın patlak vermesi ülke açısından yeni bir ekonomik darboğazın yaşanmasına neden olmuştur. Türkiye her ne kadar savaşa girmemiş olsa da savaşa sürüklenme ihtimali "Demokles'in Kılıcı" gibi her daim ülke üzerinde bir endişe havası yaratmıştır. Savaş döneminin olağan üstü koşulları kendisini üretim ilişkilerinin yeniden düzenlenmesi sürecinde de göstermiştir. Savaşın getirdiği iktisadi zorlukların üstesinden gelebilmek için, savaş boyunca iki farklı iktisat politikası uygulanmıştır. Başbakan Refik Saydam (1939-1942) hükümet tarafından kontrol edilen ve özel teşebbüsün kendi isteği doğrultuda hareket edemeyeceği sık1 kontrol politikası uygulamış ve uygulanan sabit fiyat politikası sonucu milli sermaye birikimi sağlanamamış, üretim düşük seviyede kalmış, fakat halk temel gıda ürünlerine ulaşmada sıkıntı çekmemiştir. Şükrü Saraçoğlu (1942-1946) ise sıkı kontrol politikasının aksi bir istikamet izleyerek, ekonomi üzerindeki devlet müdahalesini ve fiyat kontrolünü sona erdirmiş, bu yolla üretimi arttırmayı amaçlamıştır. ${ }^{79}$ Savaş dönemi boyunca uygulanan her iki ekonomi politikası da eleştirilere uğramış, Boratav, Saydam hükümetlerinin izlediği katı fiyat kontrolleri ve düşük fiyatlarla tarım ürünlerine el koyma politikalarının karaborsacılık ve istifçiliği körüklediğini ifade ederken, Doğan Avcıoğlu, Saraçoğlu döneminde uygulanan ekonomi politikasını eleştirmiş ve "mevsimsiz liberalizm" olarak değerlendirmiştir. ${ }^{80}$ Cemiyet üretim ilişkilerinin değiştiği bu dönemde de aktif olarak rol almaya çalışmıştır. Cemiyetin Genel Sekreteri Rahmi Köken 1940 yılında CHP Genel Sekreterliği'ne gönderdiği yazıda, savaş yıllarında halkın yanlış bir bilinçle altın alımına yöneldiğini, bunun sermaye birikimini olumsuz yönde etkileyeceğini, bu sebeple halkın yeniden devlet tahvili alımına ve birikimlerini Türk Lirası olarak bankalarda tutmaya yönlendirilmesi gerektiğini belirtmiştir. Köken'in uyarısının ardından CHP Genel Sekreterliği il idare heyetlerine, parti müfettişliklerine, halkevleri ve halkocaklarına savaş döneminde tasarruf ilkelerine uymamanın ihanet anlamına geldiği, vatanın müdafaası sebebi ile bütün halkın tasarruf ilkelerine uymaları, birikimlerini altın alımı yerine Türk Lirası olarak tasarruf hesaplarında ve devlet tahvillerinde değerlendirmeleri doğrultusunda yönlendirilmesi talimatını vermiştir. ${ }^{81}$ Başvekil Şükrü Saraçoğlu 1942 yılında Tasarruf ve Yerli Malı Haftası kapsamında yapmış olduğu konuşmada, devletin Varlık vergisi gibi halkın fedakarlığını gerektiren tedbirlere başvurmak zorunda kaldığını belirtirken, halkın artık saltanat döneminin boynu bükük yurttaşları olmadığını, bu duruma cumhuriyetin kazanımları sayesinde gelindiğini ve vaziyeti korumak için fedakarlıklar yapılması gerektiğini, bunun milli bir borç olduğunu ifade etmiştir. ${ }^{82} 1945$ yılında yaptı̆ğ konuşmasında ise yapılan fedakarlıklar sayesinde devletin savaş dönemini başarıyla atlattığını fakat zaruri şartların bir sonucu olarak ortaya çıkan hayat

\footnotetext{
77 "İsmet Paşa Hazretleri", İktisat ve Tasarruf, C. 3, S. 2, Ocak 1934, s. 5.

78 "En Emin, En Sağlam, En Kârlı Tasarruf Yolu: Dahili İstikraz Tahvilleri Almaktır", İktisat ve Tasarruf, C.2, S. 3, Şubat 1933, s. 2-3.

${ }_{79}$ Cemil Koçak, Türkiye'de Milli Şef Dönemi (1938-1945) (Cilt 2), İletişim Yayınları, İstanbul 2007, s. 412-432.

${ }^{80}$ Korkut Boratav, age, s. 293; Doğan Avcioğlu, Türkiye'nin Düzeni: Dün Bügün Yarın-1, Tekin Yayınevi, İstanbul 1976, s. 472.

${ }^{81}$ DAB: Tasarruf ve Yerli Malı Haftası Kutlamaları, 490.1.0.0/1453.23.1, 16.11.1940.

82 DAB: Başbakan Şükrü Saraçoğlu'nun, Tasarruf ve Yerli Mallar Haftası ile İlgili Olarak, Ankara Halkevinde Sunduğu Nutuk, 30.1.0.0/11.63.34, 12.12.1942.
} 
pahalılığının bir süre daha devam edeceğini, halkın bir süre daha fedakarlıklarına devam etmesi gerektiğini belirtmiştir. ${ }^{83}$

Althusser'in vurguladığı üzere devletin ideolojik aygıtlarının özelliklerinden biri aynı hedef doğrultusunda müşterek hareket edebilmeleridir. Egemen ideoloji, farklı aygitlar arasında hedef birliği sağlamakta ve müştereklik tesis etmektedir. Tasarruf ve Yerli Malı Haftası kapsamında yürütülen faaliyetler farklı ideolojik aygıtların müşterekliğini ortaya koyan önemli birer örnek olmuşlardır. Türk Ocakları ve sonrasında kurulan halkevleri faaliyetlerini yürütmesi bakımından cemiyete destek veren başlıca kurumlar olmuşlardır. Cumhuriyet Halk Partisi, il idare merkezleri aracılığı ile yurdun tüm illerinde devlet kurumlarının ve halkın yönlendirilmesi görevlerini yerine getirmişlerdir. ${ }^{84} \mathrm{Bu}$ dönemde, Tasarruf ve Yerli Malı Haftası kapsamında müftülüklerden cemiyetin gayelerinin halka tanıtılması için camilerde telkinde bulunulması ve minarelere mahya asılması talep edilmiştir. Verilen hutbe ve vaazlarda tasarruf yapmanın milli bir borç olduğu, yapılan birikimlerin bankalarda değerlendirilerek 100 milyonu bulan tasarruf hesaplarının artarak 500 milyona erişmesi doğrultusundaki milli hedefin gerçekleştirilmesine katkı sağlanacağının vurgulanması istenmiştir. ${ }^{85}$

\section{Cemiyetin Üreticilere Yönelik Faaliyetleri}

Cemiyet, halkın iktisadi kültür birikimi elde etmesi, tüketim alışkanlıklarını değiştirerek tasarruf sağlaması ve elde edilen tasarrufların sermaye birikimine dönüştürülmesi yönünde aracı bir aktör olarak rol almakla birlikte, üretim ilişkilerinin dönüşümünde de önemli görevler üstlenmişti. Cemiyetin bu sahada yürüttüğü faaliyetlerin hedef kitlesi ise sanayici, çiftçi ve ticaret kesimleri olmuştur. Üretim ilişkilerinin köklü bir şekilde değiştiği bu dönemde Cemiyetin başlıca fonksiyonu, bu sürecin şekillenmesini belirleyecek politikaların oluşması için tartışma ortamı sağlamanın yanı sıra, yerli üretimin gelişebilmesi bakımından üreticilerin yönlendirilmesi, yerli malların yurt içinde ve yurt dışında tanıtılması olmuştur.

Cemiyet, küresel kriz sonrası dönemde, sanayi politikasının belirlenmesi bakımından 22 Nisan 1930 tarihinde Birinci Sanayi Kongresi'ni düzenlenmiştir. ${ }^{86}$ Rahmi Köken tarafından yapılan konuşmada, düzenlenen sanayi kongresinin hedefinin yerli malı kullanması özendirilen halk için kaliteli ve ucuz mal üretebilmek doğrultusunda sanayinin modernleştirilmesi için gerekli tedbirlerin görüşülmesi ve ortak bir eylem planının oluşturulması olduğu belirtilmişti. ${ }^{87}$ Kongrenin yönetmeliğinde de arzu edilen sanayileşme planı ile "halkın ve devletin himaye ve fedakarlığına dayanarak yaşayabilen suni bir varlık haline gelmiş bir sanayi yapısının yerine, kuvvetini modern sanayinin hesap ve bilgi kaynaklarından alan sağlam ve canlı" bir sanayi

\footnotetext{
${ }^{83}$ DAB: Başbakan'ın, Tasarruf ve Yerli Malları Haftası Münasebeti ile Yaptı̆̆ Açılış Konuşması, 30.1.0.0/11.64.9, 12.12.1945.

${ }^{84}$ CHP genel merkezi, Yerli Malı ve Tasarruf Haftası kutlamaları kapsamında illerde yürütülecek faaliyetler hakkında il idare heyetlerine program göndererek, tüm ulusun bu kutlamalara katılması talimatı vermiştir. CHP Seyhan, Antalya, Aydın ve Yozgat il idare heyetleri tarafından Genel Merkeze gönderilen raporlarlarda Yerli Malı ve Tasarruf Haftası kutlamaları kapsamında okullarda tanıtım programları, sergiler ve öğrenci yürüyüşleri düzenlendiği, halkın tasarruf bilincinin arttırılması için yoğun çaba harcandığı bildirilmiştir. DAB: 10. Tasarruf ve Yerli Malı Haftası'nın Kutlanma Şeklini Gösteren Tamim, 490.1.0.0/4.21.31, 10.11.1939; DAB: Tasarruf ve Yerli Malları Haftası'nda Halkevlerinde Yapılan Faaliyetler, 490.1.0.0/14.76.2, 09.01.1935.

${ }^{85}$ DAB: Milli İktisat ve Tasarruf Cemiyeti'nin Gayesinin Halka tanıtılması İçin Minarelere Mahya Asılması ve Camilerde bu Kanunun Halka Anlatılmast, 51.0.0.0/3.17.23, 26.12.1929; DAB: Milli iktisat ve Tasarruf Cemiyeti'nin 4. Tasarruf ve Yerli Malları Haftası Dolayısıla Halkın Tasarrufa ve Yerli Mallarına Özendirilmesi Hususlarının Vaazlarda İşlenmesi Talebi, 51.0.0.0/12.101.20, 28.11.1934; DAB: Onuncu Tasarruf ve Yerli Malı Haftası Münasebetiyle Tasarruf Hakkında Yazılmış Hutbelerin Okunması, 51.0.0.0/4.36.9, 20.02.1939.

${ }^{86}$ Tekeli ve İlkin'e göre Cemiyet'e böyle bir kongre düzenletilmesinin sebeplerinden biri sunulan bu planın ihtiyaçları karşılayamamış olmasıdır. İlhan Tekeli-Selim İlkin, age, s. 122.

${ }^{87} 1930$ Sanayi Kongresi Raporlar ve Zabitlar, İktisat ve Tasarruf Cemiyeti, Ankara 1930, s. 717-719.
}

\section{History Studies}


yapısına ulaşmak olduğu belirtilmiştir. ${ }^{88}$ Ortaya konan bu hedef doğrultusunda sanayi üreticileri sektörler bazında gruplara ayrılmış ve her gruptan kendilerine sunulan başlıklar doğrultusunda bir rapor düzenlemeleri istenmiştir. ${ }^{89}$ Toplanan raporlar ülkenin üretim kapasitesinin belirlenmesi için güvenilir bir kaynak olmuş, elde edilen veriler 1şı̆̆ında nasıl bir sanayi politikası izlenmesi gerektiği yönünde çalışma yürütmek maksadıyla 17 ihtisas encümeni seçilmiştir. $\mathrm{Bu}$ encümenler tarafından hazırlanan raporlar genel kurulda görüşülerek tartışılmıştır. Encümen raporlarında on yıllık genel bir sanayileşme planı oluşturulması, yeni sanayi yatırımlarının bu plana uygun olarak yapılması ve sürecin işlerliğini sağlayacak bir denetim mekanizmasının tesisi gerekli görülmüştür. ${ }^{90}$ Sunulan öneriler incelenirken dikkat edilmesi gereken önemli bir husus Kongrenin yapıldığı tarihte devletçilik fikrinin Beşvekil tarafından henüz telaffuz edilmemiş olmasıdır. Bu sebeple Sanayi Kongresi'nde devletin müdahaleci bir aktör olarak liderlik ettiği planlı bir iktisat politikası fikri ortaya çıkmakla birlikte, devletin bu süreçte üretici bir aktör olarak yer alması öngörülmemiştir.

Çağlar Keyder, sanayi kongresi çerçevesinde oluşturulan örgütlenme modelinin Mussolini dönemi corporazione'lerine benzediğini belirtmektedir. Keyder'e göre, Milli İktisat ve Tasarruf Cemiyeti ekseninde yürütülen girişimler, hükümetin toplumsal örgütlenme alanını, sadece doğrudan doğruya değil, aynı zamanda ideolojik aygıtlarla işgal etme çabalarının bir yansımasıdır ve Avrupa'da gelişmeye başlayan faşist yönetimlerden esinlenilmiştir. ${ }^{91}$ Burada, Cemiyetin devletin ideolojik aygıtı olarak toplumsal örgütlenme alanını yönlendirici bir misyon üstlenmekle birlikte, yöneliminin Avrupa'daki faşist yönetimlerden farklı olduğunu belirtmek gerekmektedir. Cemiyet üyeleri açısından ulaşılmak istenen milli sanayi yapısının önemli bir özelliği, zaman içerisinde devlet desteği ve himayesinden uzaklaşarak, uluslararası ticaretin kendi dinamikleri ekseninde kâr ve zarar hesabının rasyonel olarak yapıldığı bir yapıya ulaşmasıdır. Bu bir anlamda bir özerkleşme sürecidir. Cemiyetin 1933 yılındaki kongresinde, başlamış olan sanayi hamlesinin gidişatına dair ortaya konulan görüşlerde bu doğrultudadır. Bu Kongrede varılan sonuçlara göre, rekabet kabiliyetinden yoksun, devlet yardımına ve devlet korumasına muhtaç bir sanayi gelişmektedir ve bu durum arzu edilen bir ilerleme modeli değildir. Cemiyet üyelerine göre, teknik işletme yetersizliğinin yanında bu sonucun ortaya çıkmasının temel nedenlerinden biri sanayi işletmelerinin ve yatırımlarının rasyonel bir şekilde yönetilmemesidir. ${ }^{92}$ Cemiyetin dergisinde, üreticilere yönelik çağrılara bakıldığında da bu yönelimi gözlemlemek mümkündür. "Himaye himayesizliğe götüren yoldur" sloganı ile üreticilerin devlet himayesine dayanan bir üretim anlayışını terk etmeleri, dünyadaki iktisadi gelişmeleri takip etmeleri, rekabet gücü elde edebilmek bakımından evrensel iktisadi normlar ekseninde planlı bir şekilde çalışmaları gerektiği sıklıkla vurgulanmıştır. ${ }^{93}$

Cemiyet üyelerince sanayileşmenin ve milli iktisadi gelişimin uluslararası iktisadi sisteminin rasyonel işleyişi ekseninde şekillenmesi arzulanmakla birlikte, bu seviyeye ulaşabilmek bakımından devletin kontrol ve desteğinde planlı bir kalkınma sürecinin yürütülmesi elzem gözükmektedir. Bunun temel nedeni, yerli sanayi kuruluşlarının henüz uluslararası alanda rekabet edebilecek seviyede olmamasıdır. Plansız girişim teşebbüsleri,

\footnotetext{
${ }^{88}$ Age, s. VI.

Sektör temsilcilerinden istenenen raporların şu başlıklar altında düzenlenmesi istenmiştir:1)Hammadde, 2)Sermaye ve kredi, 3)Vergi ve rüsum, 4)Teşvik-i Sanayi Kanunu ve uygulaması, 5)Standart Meseleleri, 6)Rasyonalizasyon meseleleri, 7)Ticaret ve Sanayi Odalarında sanayicileri temsili, 8)Sanayi eğitimi, 9)Nakliyat meseleleri.

${ }^{90}$ Age, s. 501-503.

${ }^{91}$ Çağlar Keyder, Türkiye'de Devlet ve Sinıflar, İletişim Yayınları, İstanbul 2010, s. 125-126.

92 "Cemiyetimizin Kongresi", Iktisat ve Tasarruf, C. 2, S. 6, Mayıs 1933, s. 4-5.

93 "Sanayici! Halkın Rağbetine Layık Olduğunuzu Gösteriniz", İktisat ve Tasarruf, C. 1, S. 6, Mayıs 1932, s. 2; "Sanayici", İktisat ve Tasarruf, C. 1, S. 5, Nisan 1932, s. 3.
}

\section{History Studies}


yüksek faizlerle alınan borçların ödemesini aksatarak sınırlı olan sermayenin de tükenmesine neden olmaktadır. Bunun yanında, piyasanın isteklerini önceden hesap etmeden, rekabet şartlarını, ulaştırma ve altyapı koşullarını yeteri kadar araştırmadan kurulan pek çok sanayi müesseseleri amansız bir rekabet sahası ortaya çıkarmıştır. Ayrıca, fiyatların düşmesi karşısında kaliteninde aynı şekilde düşmesi, halkın yerli mallara olan talebini azaltmıştır. Bu sebeplerle, sanayi kuruluşlarında kaliteli ve ucuz mal üretebilecek, hem ileri teknikli hem de rantabl müesseselerin kurulumunu önceden emniyet altına alacak sıkı bir işletme kontrolüne ihtiyaç bulunmaktadır. ${ }^{94}$ Cemiyet üyelerince sunulan plan fikri, daha sonra hükümetin yöneleceği iktisat programının ana eksenini oluşturmuş, Sovyet Birliği'nin planlı ekonomide elde ettiği başarıların Türkiye'de uyandırdığı etki de planlı ekonomi modeline geçişte önemli bir etken olmuştur.

Cemiyet sanayileşme sürecine katkıda bulunabilmek bakımından yerli üreticilerin ürünlerini tanıtabilecekleri pek çok sergi düzenlemiştir. Bu sergilerden ilki 1930 tarihinde Sanayi Kongresi'ne hazırlık mahiyetinde düzenlenen Milli Sanayi Numune Sergisi olmuştur. ${ }^{95}$ Müteakip yıllarda da Milli Sanayi sergileri düzenlenmeye devam edilmiştir. Bu sergilerin yanında yurdun diğer illerinde de yerli ürünlerin tanıtıldığı çok sayıda sergi açılmıştır. Tanıtım faaliyetlerinin daha iyi yapılabilmesi bakımından Ankara'da bir sergi evi yapılmıştır ve yıl boyunca sergi açık kalmıştır. ${ }^{96}$ Cemiyet, yurt dışında açılan fuarlara da büyük önem atfedilmiştir. Bu fuarlar aynı zamanda Türkiye'nin yurt dışı imajının geliştirilmesi bakımından önemli bir avantaj olarak görülmüştür. Cumhuriyetin göstermiş olduğu başarıları anlatabilmek için standlara eski Türkiye ve Yeni Türkiye başlıkları altında fotoğraflar konulmuştur. Düzenlenen faaliyetlerde aktif olarak yer alan Tör, bu sergilerde ülkenin göstermiş olduğu ilerlemenin büyük takdir topladığını belirtmiştir. ${ }^{97}$

Volume 11

Issue 2

A tribute to

Prof. Dr.

Mehmet Ali

ÜNAL

April

2019

Cemiyet, yerli ürün satan ticaret kesiminin satışlarını arttırabilmesi bakımından yönlendirici ve eğitici bir rol üstlenmiştir. Bu bağlamda, ticaret kesimine reklam vermeleri ve iyi hizmet sunmaları konusunda çağrıda bulunmus, yerli ürün satan mağazaların hizmet kalitesini yükseltmek için güzel vitrin yarıșmaları düzenlemiștir. Cemiyet üyeleri üretilen yerli malların halka ucuz ve kaliteli olarak sunulmasının milli iktisadi işleyişin temel kriterleri olarak görmüşlerdir. $\mathrm{Bu}$ sebeple yerli ürünlere etiket zorunluluğu getirilmesini, böylelikle halkın üreticiden kaynaklanan şikayetlerinin giderilebilmesi doğrultusunda kontrollerin sağlanmasını önermişlerdir. ${ }^{98}$ Cemiyet bu anlamda tüketici haklarının korunması için yoğun çaba harcamış, karaborsacılık yapanlar hakkında sert tedbirler alınması gerektiği savunmuştur. ${ }^{99}$ Meclis Başkanı Kazım Karabekir de cemiyet şubelerinin yerli ürünlerden şikayeti olan vatandaşlar için bir başvuru mekanizması olduğunu belirtmiştir. ${ }^{100}$

Cemiyet, sanayileşme alanında üstlendiği misyonu ziraat alanında yerine getirmeye çalışmıştır. Bu bağlamda zirai üretim alanında mevcut problemleri ele almak ve çözüm önerileri sunabilmek amaciyla 14 Ocak 1931 tarihinde Ankara'da Birinci Ziraat Kongresi'ni

\footnotetext{
94 "Cemiyetimizin Kongresi", İktisat ve Tasarruf, C. 2, S. 6, May1s 1933, s. 4-5.

95 Düzenlenen Milli Sanayi Numune Sergisi ve Sanayi Kongresini desteklemek bakımından ayrıca Sergi ve Kongre isimli kısa süreli bir dergi yayını yapılmıştır. Bknz. İlhan Tekeli-Selim İlkin, 1929 Dünya Buhranında Türkiye'nin Íktisadi Politika Arayışları, Ortadoğu Teknik Üniversitesi, Ankara 1977, s. 120.

${ }^{96} \mathrm{Bu}$ sergi evi dönemin en önemli mimarlarından biri olan Mimat Şevki Balmumcu tarafından projelendirilmiştir. 1948 yılında ise Mimar Paul Bonatz'ın tasarımı ile bugünkü Opera binasına dönüştürülmüştür. Bknz. İlhan TekeliSelim İlkin, age. s. 120; "İktisat ve Tasarruf Cemiyetinin İlk Sergi Evi İnşaatı Bu Ay Bitiyor", İktisat ve Tasarruf, C.3, S. 10, Eylül 1934, s. 5.

${ }^{97}$ Vedat Nedim Tör, "Leipzig Sergisinde Türk Sesi", Iktisat ve Tasarruf, C. 1, S. 5, Nisan 1932, s. 8.

98 "Cemiyetimizin Kongresi", Iktisat ve Tasarruf, C. 2, S. 6, May1s 1933, s. 4-5.

99 "Yerli Mallar Üzerinde İhtikâr Alçaklıktır", İktisat ve Tasarruf, C. 1, S. 5, Nisan 1932, s. 7.

100 "İsmet ve Kazım Paşa'ların Muhim Nutukları", Cumhuriyet, 13 Aralık 1930, s. 1, 4.
}

\section{History Studies}


düzenlemiştir. ${ }^{101}$ Kongre öncesinde kapsamlı bilgilerin elde edilebilmesi için ziraat odalarından kendi bölgelerinde bölgesel ziraat kongreleri düzenlemeleri ve kendilerine sunulan gündem maddeleri hakkında bilimsel raporlar hazırlamaları talep edilmiştir. Düzenlenen bölgesel kongrelerde her tarım ürünü için bir encümen tesis edilmiştir. Her encümenden bir veya iki temsilci kongreye katılarak, diğer bölgelerden gelen temsilcilerle ortak çalışma yapmış, kendi konuları ile ilgili raporlar hazırlamışlardır. ${ }^{102}$ Encümenler tarafından sunulan raporlar incelendiğinde, tarımsal üretimin geri tekniklerle yürütülüyor olması, modern tarım araçlarının ve eğitimli insan kaynağı eksikliği, kredi imkanlarının sınırlı olması, üretim kalitesinin uluslararası rekabet koşulları bakımından düşük olması, üretim girdi maliyetlerinin buhran nedeniyle yüksek olması, ulaşım imkanlarının sınırlı olması, dış pazara ulaşım konusunda aracı kurumların yetersizliği ve tarımsal ürün fiyatlarının düşük olması zirai üretimin gelişimini engelleyen temel sorunlar olarak ön plana çıktığı görülmüştür. ${ }^{103}$ Ortaya konan ihtiyaçlar doğrultusunda cemiyet ağırlıklı olarak yerli tarım ürünlerinin yurt içinde ve yurt dışında tanıtılması için sergi faaliyetlerinde bulunmuştur. Ülke ihracatının ağırlıklı bölümünü oluşturan tarımsal ürünlerin yurt dışı pazarını genişletmek için büyük çaba sarfedilmiştir. Cemiyetin 1931 yılında Budapeşte'de uluslararası sergide açtığı stand, Macar gazetesi Azest'in yürüttüğü anket sonucunda, 80 bin oy ile birinci seçilmiştir. ${ }^{104}$ Yerli tarım ürünlerinin tanıtılmasının yanında çiftçilerin daha ileri üretim teknikleri ile kaliteli ve rekabet gücü yüksek ürünler yetiştirmeleri için eğitim faaliyetlerine de ağırlık verilmiştir. Bu bağlamda Birinci Ziraat Kongresi ile eş zamanlı açılan ziraat teknik sergisinde tarımsal üretim tekniğinin geliştirilmesi için gerekli olan tarım araçlarının, zararlı bitki ve böceklerden korunmak için kullanılan tarım ilaçlarının, ürün verimini arttırmak için kullanılan suni gübrelerin tanıtımı yapılmıştır.

Cemiyetin devlet ve toplum arasında aracilık yapma fonksiyonu ziraat alanında büyük önem taşımaktaydı. Bunun en önemli nedeni, ekonomik krizin etkisinin en fazla hissedildiği alanın tarım olmuş olmasıdır. Kriz sebebiyle, dünya genelinde olduğu gibi, Türkiye'de de tarımsal fiyatlar hızla düşmüştür. ${ }^{105}$ Özellikle Ege bölgesi gibi dış pazara yönelik üretim yapan yörelerde buhranın neden olduğu fiyat düşüşü daha da etkili olmuştur. Dönemin tarım politikası ise tarımsal ürün fiyatlarının düşük seviyede tutulması yönünde şekil almıştır. Böylelikle, takas ve kliring sistemlerine gidilerek ihracatın arttırılabileceği öngörülmüştür. İzlenen düşük fiyat politikası doğal olarak beraberinde tepkileri de doğurmuştur. Tarımsal girdilerin maliyetinin artması ve kredi olanaklarının yetersiz kalması özellikle küçük ölçekli üreticileri zorlamıştır. ${ }^{106}$ Fiyatların düşük olması sebebi ile elde ettiği üretimden yeteri kadar kar elde edemeyen üreticiler, bankalardan aldıkları kredileri ödemekte zorlanmışlardır. Birinci Ziraat Kongresinde sunulan raporlarda ödeme güçlüğü çeken ve kredi alma imkanı bulamayan üreticilerin \% 50 ile \% 120 arasında faiz talep eden tefecilerden borç almak durumunda kaldıkları belirtilmiş ve devletin üreticiye destek olması istenmiştir. ${ }^{107}$ Yerli Malı ve Tasarruf Haftası açılışı dolayısı ile yaptığı konuşmada tarım kesiminden gelen tepkilere değinen Başvekil İnönü, dış piyasada tarım ürünlerinin fiyatlarının yüksek olması sebebi ile ucuz fiyat politikasının gerekli olduğunu

\footnotetext{
${ }^{101}$ İloğlu, age, s. 38.

102 Devlet Arşivleri Başkanlı̆̆ı, Ankara'da Toplanacak Ziraat Kongresine Katılımın Arttırılması, 490. 1.0.0/1.4.3, 18.08.1930.

${ }_{103} 1931$ Birinci Ziraat Kongresi İhtisas Raporları, İktisat ve Tasarruf Cemiyeti, Ankara 1931.

${ }^{104}$ Yunus Nadi, "Peşte Sergisinde Türkiye", Cumhuriyet, 1 Haziran 1931.

105 Avni Zarakolu, "1929/1930 Dünya Ekonomik Krizi Karşısında Türk Ekonomisi ve Alınan Krizle Mücadele Tedbirleri”, Atatürk Dönemi Ekonomi Politikası ve Türkiye’nin Ekonomik Gelişmesi, Ankara Üniversitesi Siyasal Bilgiler Fakültesi Yayınlar1, Ankara 1982, s. 90.

106 İlhan Tekeli-Selim İlkin, 1929 Dünya Buhranında Türkiye'nin İktisadi Politika Arayışları, Ortadoğu Teknik Üniversitesi, Ankara 1977, s. 217-219; Bilsay Kuruç, Belgelerle Türkiye İktisat Politikası (Cilt 1), Ankara Üniversitesi Siyasal Bilgiler Fakültesi Yayınları, Ankara 1988, s. LVII-LVIII.

1071931 Birinci Ziraat Kongresi Ihtisas Raporlarl, İktisat ve Tasarruf Cemiyeti, Ankara 1931, s. 475-477, 693-699.
} 
belirtmiştir. Bunun yanında, fiyat düşüşünden kaynaklanan kaybın daha fazla üretim yapılarak ve ürün kalitesinin arttırılarak aşılabileceğini, devletinde bu doğrultuda üreticinin teknik bilgisinin arttırılması ve kredi imkanlarını kolaylaştırılması yönünde bir politika izlediğini belirtmiştir. ${ }^{108}$ Uluslararası alanda tarım ürünlerinin fiyatlarının düşük olmasının yanında devletin tarım üreticisine yönelik korumacı politika izlemesini etkileyen bir diğer faktör ise üreticilerin ürünlerinin satın alınarak depolanabileceği tesislere ve ilerleyen yıllarda 'Fisko Birlik' olarak adlandırılacak bir kuruma sahip olmamasıdır. ${ }^{109}$

Cemiyet, tarım üreticisi açısından oldukça zorlu olan bu dönemde toplumsal gerilimin düşürülmesi için çaba harcamıştır. Falih Rıfkı Atay tarafından kaleme alınan makalede, uluslararası koşullar karşısında devletin tarımsal ürünlerin fiyatlarını yükseltebilecek araçlara sahip olmadı ğını belirterek üreticilerin sabırlı olmaları gerektiğini belirtilmiş̧ir. Bunun yanında, düşük fiyatlı tarımsal ürünlerin halkın tüketim sarfiyatını azaltarak, tasarruf yapmasına imkân sağlayacağı ve bu tasarrufların da sanayileşme yolunda büyük katkı sağlayacağını belirtilerek, çiftçiler tarafından yapılan fedakarlıkların milli kalkınma sürecinin önemli bir parçası olduğu vurgulanmıştır. ${ }^{110} \mathrm{Bu}$ alanda cemiyet tarafından yürütülen bir diğer faaliyet özellikle üzüm, incir, fındık gibi krizden göreli olarak daha fazla etkilenen malların iç piyasada tüketiminin arttırılması, dolayısıyla üreticinin daha fazla gelir elde etmesi için özel kampanyalar düzenlemek olmuştur. Dergide yayınlanan bir makalede üzüm, incir gibi ürünlerin miktarında önemli bir artış sağlanmasına karşı fiyatların düşük olmasının üretici açısından problem doğurduğu belirtilmiş, bu problemle başa çıkılması için iç piyasada bu ürünlerin tüketiminin arttırılması gerektiği vurgulanmıştır. ${ }^{111}$ Cemiyet yürüttüğü kampanyada 1932 yılında Kâinat güzeli seçilen Keriman Halis Ece'yi reklam yüzü olarak kullanmıştır. Kuru yemiş yemenin sağlık açısından faydalı olduğu sloganlarla vurgulanmıştır. Cemiyetin bu kampanyasında da milliyetçi söyleme sıklıkla başvurulmuş ve fiyat düşüşü sebebi ile pazarı daralan tarımsal ürünlerin tüketiminin arttırılmasının milli bir görev olduğu vurgulamıştır. ${ }^{112}$ Benzer şekilde, halkı seferber edebilmek için ajitatif söylemlerde kullanılmıştır. Derginin Kasım 1932'de yayınlanan 12. sayısında yayınlanan bir köylü kızının fotoğrafının altına "Vatandaş! Sen incir yemezsen, incir yetiştiren bu kız aç kalır" ifadesi yazılmıştır. Benzer şekilde üzüm üreten çiftçilerin yer aldığı bir fotoğraf da "Vatandaş! Sen üzüm yemezsen, üzüm yetiştiren köylüler sefil düşerler" ifadesi ile birlikte yayınlanmıştır.

\section{Sonuc}

1930'lu yıllar Türkiye'de üretim ilişkilerinin köklü şekilde değiştiği bir dönemdir ve bu dönüşüm sürecinde, devletin izleyeceği politikalar doğrultusunda halkın yönlendirilmesi zaruri ihtiyaç olarak belirmiştir. Bu makalede, Milli İktisat ve Tasarruf Cemiyeti'nin devletin ihtiyaç duyduğu bu aracılık görevini devletin bir ideolojik aygıtı olarak yerine getirdiği ifade edilmeye çalışılmıştır. Althusser' in kavramlaştırması ele alınırken belirtildiği üzere devletin ideolojik aygıtlarının temel görevi üretim ilişkilerinin yeniden düzenlenmesi sürecinde egemen ideolojinin gücü kullanılarak halkın kendi başına eyler kılınmasıdır. İktisadi daralmanın yaşandığı kriz döneminde Cemiyetin genel olarak misyonu, izlenecek devletçi iktisat politikası doğrultusunda halkın tüketim alışkanlıklarının değiştirilmesi, yapılan tasarruflar sayesinde elde edilen birikimlerin sanayileşme programına finansal kaynak olması bakımından bankalara ve

\footnotetext{
108 "Başvekil İsmet Paşa Hazretleri", İktisat ve Tasarruf, C. 3, S. 2, Ocak 1934, s. 2-5.

109 İlhan Tekeli-Selim İlkin, 1929 Dünya Buhranında Türkiye'nin İktisadi Politika Arayışları, Ortadoğu Teknik Üniversitesi, Ankara 1977, s. 219.

${ }^{110}$ Falih Rifkı Atay, "İktisat Programı", Iktisat ve Tasarruf, C. 3, S. 3, Şubat 1934, s. 6.

111 "Bol Üzüm! Bol İncir! Bol Fındık! Fakat Düşük Fiyat. Ne Yapmalı", İktisat ve Tasarruf, C. 1, S. 11, Ekim 1932, s. $2-3$.

112 "Vatandaş! Yerli Yemiş Ye", İktisat ve Tasarruf, C. 1, S. 10, Eylül 1932, s. 4-5.
} 
devlet tahvillerine yönlendirilmesi olmuştur. Çalışmada ortaya konmaya çalışıldığı üzere cemiyet milliyetçi söylemler ile egemen ideolojinin gücünü yürüttüğü çalışmalarda yoğun bir şekilde kullanmıştır. Bununla birlikte dönemin önemli bir özelliği egemen ideolojinin kendisinin bir inşa sürecinde olmasıdır. Cumhuriyetin kurucu eliti yeni devletin inşa sürecinde yapılan reformlarla köklü bir dönüşümü gerçekleştirmeye çalışmaktaydılar. $\mathrm{Bu}$ köklü dönüşümün ideolojik tabanı bir bakıma Osmanlı döneminin siyasi, iktisadi ve kültürel yapısının red edilmesine dayanmaktaydı. Serbest Furka deneyimi ve Menemen ayaklanmas1, yürütülmekte olan reform programları ile şekillenen egemen ideolojinin toplumsal kabulünde problemler yaşandığını ortaya koymaktaydı. Bu sebeple Cemiyet faaliyetlerini egemen ideolojinin gücünden faydalanarak yürütmekle birlikte, bu ideolojinin toplumsal alanda kabul görmesi için de faaliyet göstermiştir. Dergi yayınlarında, yapılan konuşmalarda ve açılan sergilerde halkın Cumhuriyet rejimi ile bağımsızlığa kavuştuğu, medeni toplumun eşit bireyleri haline geldiği yoğun bir şekilde vurgulanarak halkın egemen ideolojiyi benimsemesi için çaba gösterilmiştir.

Halkın üretim ilişkilerinin yeniden düzenlenmesi sürecinde ideoloji ile kendi başına eyler kılınması bir anlamda fedakârlık yapılmasını da gerekli kılmaktaydı. Büyük Buhrandan en çok etkilenen kesim olan tarım üreticileri de bu süreçte en çok fedakarlık yapması istenen kesim olarak ön plana çıkmıştır. Tarım ürünleri fiyatlarının dış piyasada düşük seyretmesi, devletin düşük fiyatlardan kaynaklanan zararları sübvanse edecek donanımdan yoksun olması, tarım üreticileri açısından oldukça zor koşullarda üretim yapmaya devam etmelerini zorunlu kılmaktaydı. Çalışmada ortaya konmaya çalışıldığı üzere, cemiyet bu zor koşullar altında yapılan fedakârlıkların ortaya çıkardığı toplumsal gerilimi düşürmek için de aracı bir rol üstlenmiştir. Halkı yerli tarım ürünlerine yönlendirerek, bu ürünlerin tüketiminin artmasını sağlamış ve bu yolla tarım kesimine destek olmaya çalışmıştır. İkinci Dünya Savaşı yıllarının olağanüstü koşullarında cemiyet, Tasarruf ve Yerli Malı Haftası kapsamında yürütmeye devam ettiği faaliyetlerde milliyetçi söylemler ile halkı istenen fedakârlıklar doğrultusunda yönlendirmeye devam etmiştir.

1930'lu yılların ilk yıllarında "altın çağını" yaşayan devletçilik, 1937'den sonra dinamizmini yitirmeye başlamış, şavaş yıllarında ivme kaybetmiş ve 1948'de yapılan Türkiye İktisat Kongresi, 1950'lerde kabul edilecek olan liberal iktisat politikaların yolunu açmıştır. ${ }^{113}$ Savaş sonrası dönemde gittikçe etkisi azalan Cemiyet, liberal politikalara hız verilmesi ile işlevini yitirmiş ve her yıl kutlanan Tasarruf ve Yerli Malı Haftası ile hatırlanır olmuştur.

${ }^{113}$ Zafer Toprak, "Unutulan Kongre:1948 Türkiye İktisat Kongresi", İktisat Dergisi, S. 211-212, Haziran-Temmuz 1982, s. 37. 


\section{Kaynakça}

AHMAD, Feroz, The Making of Modern Turkey, Routledge Publications, New York 2003.

AHMAD, Feroz, The Quest for Identity, Oneworld Publications, Oxford 2003.

AHMAD, Feroz, İttihatçıllktan Kemalizme, Kaynak Yayınları, İstanbul 1996.

AHMAD, Feroz, The Turkish Experiment in Democracy 1950-1975, C. Hurst\&Company, London 1977.

ALTHUSSER, Louis, İdeoloji ve Devletin İdeolojik Aygitlarl, Çev.: Alp Tümertekin, İletişim Yayınları, İstanbul 2000.

Atatürk'ün Söylev ve Demeçleri (1919-1938), Atatürk Araştırma Merkezi, Ankara 2006.

ATAY, Falih Rıfkı, "İktisat Programı", İktisat ve Tasarruf, C. 3, S. 3, Şubat 1934, s. 6.

AVCIOĞLU, Doğan, Türkiye'nin Düzeni: Dün Bügün Yarın-1, Tekin Yayınevi, İstanbul 1976.

BORATAV, Korkut, 100 Soruda Türkiye'de Devletçilik, Gerçek Yayınları, İstanbul 1974.

BORATAV, Korkut, Türkiye'de Devletçilik, İmge Kitabevi Yayınları, İstanbul 2005.

DUMAN, Doğan, Milli İktisat ve Tasarruf Cemiyeti, (Dokuz Eylül Üniversitesi Atatürk İlkeleri ve İnkılap Tarihi Enstitüsü, Yayınlanmamış Yüksek Lisans Tezi), İzmir, 1990.

ERTAN, Temuçin Faik, Kadrocular ve Kadro Hareketi, T.C. Kültür Bakanlığı, Ankara 1994.

FAİK, Sabiha, "Milli İktisat ve Kadınlarımız", Ikktisat ve Tasarruf, C.1, S.6, Mayıs 1932, s. 6.

GÜVEN-TOKER A Biographical Study of a Utopian Intellectual: Şevket Süreyya Aydemir, (Yeditepe Üniversitesi Sosyal Bilimler Enstitüsü, Yayımlanmamış Doktora Tezi), İstanbul 2019.

IŞIK, Şevket, "Türkiye'de Kentleşme ve Kentleşme Modelleri", Ege Coğrafya Dergisi, S. 14, 2005, s. 57-71.

İLOĞLU, Asım Süreyya, Türkiye Ekonomi Kurumunun Kuruluşu ve 1929-1973 Yılarındaki Çalışmalarına Toplu Bir Bakış, Türkiye Ekonomi Kurumu Yayınları, Ankara 1974.

İNAN, Ayşe Afet, İzmir İktisat Kongresi: 17 Şubat-4 Mart 1923, Türk Tarih Kurumu Yayınları, Ankara 1989.

İNÖNÜ, İsmet, "Fırkamızın Devletçilik Vasfı", Kadro, C. 2, S. 22, Ekim 1933, s. 4-6.

KARPAT, Kemal, Türk Demokrasi Tarihi, Timaş Yayınları, İstanbul 2010.

KARAOSMANOĞLU,Yakup Kadri, "Atatürkçülüğün Ekonomik ve Sosyal Yönü Semineri", İktisadi ve Ticari İlimler Akademisi, İstanbul 12-13 Ekim 1973, s.50. 
KEMAL, Kadri, "Lozandan Önceki ve Sonraki Türkiye", İktisat ve Tasarruf, C. 4, S. 5, May1s 1935, s. 2-4.

KEYDER, Çağlar, Türkiye'de Devlet ve Sinıflar, İletişim Yayınları, İstanbul 2010.

KOÇAK, Cemil, Türkiye'de Milli Şef Dönemi (1938-1945) (Cilt 2), İletişim Yayınları, İstanbul 2007.

KURUÇ, Bilsay, Belgelerle Türkiye İktisat Politikası (Cilt 1), Ankara Üniversitesi Siyasal Bilgiler Fakültesi Yayınları, Ankara 1988.

LEWIS, Bernard, The Emergence of Modern Turkey, Oxford University Press, London 1968.

MARDİN, Şerif, Türkiye'de Toplum ve Siyaset, İletişim Yayınları, İstanbul 1990.

NABİ, Yaşar, "Ergani İstikrazı", İktisat ve Tasarruf, C. 3, S. 10, Eylül 1934, s. 4.

NADİ, Yunus, "İktisad Haftasının 4üncü Günü", Cumhuriyet, 16 Aralık 1938.

NADİ, Yunus, "Peşte Sergisinde Türkiye", Cumhuriyet, 1 Haziran 1931.

TÖR, Vedat Nedim, "Leipzig Sergisinde Türk Sesi", İktisat ve Tasarruf, C. 1, S. 5, Nisan 1932, s. 8-9.

SAKA, Remzi, Sermaye ve Kredi Hareketleri, Tecelli Matbaası, Ankara 1933.

SEMIZ, Yaşar, 1929-1938 Döneminde Milli İktisat ve Tasarruf Cemiyeti, (Selçuk Üniversitesi Sosyal Bilimler Enstitüsü, Yayınlanmamış Doktora Tezi), Konya, 1991.

SÜREYYA, Şevket, "Cihan Biriktiriyor", Cumhuriyet, 12 Aralık 1930, s. 2.

SÜREYYA, Şevket, Mektep Kooperatifçiliği ve Tasarruf Terbiyesi, Milli İktisat ve Tasarruf Cemiyeti, Ankara 1932.

TEKELİ, İlhan- Selim İlkin, 1929 Dünya Buhranında Türkiye'nin İktisadi Politika Arayışları, Ortadoğu Teknik Üniversitesi, Ankara 1977.

TEKELİ, İlhan-Selim İlkin, Uygulamaya Geçerken Türkiye'de Devletçiliğin Oluşumu, Ortadoğu Teknik Üniversitesi, Ankara 1982.

TEKELİ, İlhan- Selim İlkin, Bir Cumhuriyet Öyküsü Kadrocularl ve Kadro'yu Anlamak, Tarih Vakfı Yayınları, İstanbul 2003.

TOKER, Mehmet Şevki, An Islamist Intellectual in Turkish Political Life: An Intellectual and Political Biography of Necip Fazll Klsakürek (1904-1983), (Yeditepe Üniversitesi Sosyal Bilimler Enstitüsü, Yayımlanmamış Doktora Tezi), İstanbul 2018.

TOKGÖZ, Erdinç, Dünden Bugüne Türkiye Ekonomi Kurumu, İmaj Yayınevi, Ankara 2004.

TOPRAK, Zafer, "Unutulan Kongre:1948 Türkiye İktisat Kongresi", Ikktisat Dergisi, S.211-212, Haziran-Temmuz 1982, s. 37-42.

TÖR, Vedat Nedim, Yıllar Böyle Geçti, Yapı Kredi Yayınları, İstanbul 1999. 
TÜRK, İsmail, "Atatürk ve Türk Mali Sistemi", Atatürk Dönemi Ekonomi Politikası ve Türkiye'nin Ekonomik Gelişmesi, Ankara Üniversitesi Siyasal Bilgiler Fakültesi Yayınları, Ankara 1982, s. 7-22.

YÜCEKÖK, Ahmet, Türkiye'de Parlamentonun Evrimi, Ankara Üniversitesi Siyasal Bilgiler Fakültesi Yayınları, Ankara 1983.

ZARAKOLU, Avni, "1929/1930 Dünya Ekonomik Krizi Karşısında Türk Ekonomisi ve Alınan Krizle Mücadele Tedbirleri", Atatürk Dönemi Ekonomi Politikass ve Türkiye'nin Ekonomik Gelişmesi, Ankara Üniversitesi Siyasal Bilgiler Fakültesi Yayınlar1, Ankara 1982, s. 89-104.

HYPERLINK "http://www.tek.org.tr/tarihce.php" http://www.tek.org.tr/tarihce.php (E.T. 15.02.2019).

\section{Süreli Yayınlar}

"Başvekil İsmet Pş. Hz. Tasarruf ve Yerli Malı Haftasını Bu Nutukla Açtı", İktisat ve Tasarruf, C.1, S. 2, Ocak 1932, s. 6-8.

"Başvekilimizin Sözleri", İktisat ve Tasarruf, C.2, S. 2, Ocak 1933, s. 2-4.

"Başvekil İsmet Paşa Hazretleri", İktisat ve Tasarruf, C. 3, S. 2, Ocak 1934, s. 2-5.

"Birinci 5 Yıllık Endüstri Programının Tatbikatı", Ulusal Ekonomi ve Arttırma, C. 5, S. 9, Eylül 1936, s. 2-3.

"Bol Üzüm! Bol İncir! Bol Fındık! Fakat Düşük Fiyat. Ne Yapmalı", İktisat ve Tasarruf, C. 1, S. 11, Ekim 1932, s. 2-3.

Volume 11

Issue 2

A tribute to

Prof. Dr.

Mehmet Ali

ÜNAL

April

2019

"Cemiyetimizin Kongresi", İktisat ve Tasarruf, C. 2, S. 6, Mayıs 1933, s. 4-5.

"Çocuğunun Tahsilini, saadetini düşünen baba hiç durmadan derhal Ziraat Bankasına gider ve bir kumbara alır", Iktisat ve Tasarruf, C.1, S. 2, Ocak 1932, s. 15.

"En Emin, En Sağlam, En Kârlı Tasarruf Yolu: Dahili İstikraz Tahvilleri Almaktır", İktisat ve Tasarruf, C.2, S. 3, Şubat 1933, s. 2-3.

"Her Türk, Türkiye Malı Kullanmalı! Niçin?", Iktisat ve Tasarruf, C.1, S. 1, Ocak 1931, s. 3-4.

"İktisat ve Tasarruf Cemiyetinin İlk Sergi Evi İnşaatı Bu Ay Bitiyor", İktisat ve Tasarruf, C. 3, S. 10, Eylül 1934, s. 5.

"İlk Hedef Akdenizdi. İkinci Hedef: İktisat”, İktisat ve Tasarruf, C. 1, S.1, Aralık 1931, s. 2

"İsmet Paşa Hazretleri", İktisat ve Tasarruf, C. 3, S. 2, Ocak 1934, s. 2-5.

"İsmet ve Kazım Paşa'ların Muhim Nutukları", Cumhuriyet, 13 Aralık 1930, s. 1, 4.

"İş Bankası Kumbaraları, İktisat Seferberliğinin Cephanesidir. Vatandaş, İktisat Harbinde Silahlan", Iktisat ve Tasarruf, C.1, S. 2, Ocak 1932, s. 16.

"Leipzig Sergisinde Türk Sesi", Kadro, S. 3, Mart 1932, s. 38-39.

"Lozandan Önce, Lozandan Sonra", İktisat ve Tasarruf, C. 3, S.12-13, Aralık 1934, s. 7-8.

"Mühim Bir Mukayese", Ikktisat ve Tasarruf, C.1, S. 9, Ağustos 1932, s. 6.

"Paranı Evde Bırakma", Iktisat ve Tasarruf, C. 1, S. 2, Ocak 1932, s. 5.

\section{History Studies}


"Sanayici", Iktisat ve Tasarruf, C. 1, S. 5, Nisan 1932, s. 3.

"Sanayici! Halkın Rağbetine Layık Olduğunuzu Gösteriniz", İktisat ve Tasarruf, C. 1, S. 6, Mayıs 1932, s. 2.

"Tasarruf Ne Demektir", Iktisat ve Tasarruf, C.1, S.1, Aralık 1931, s. 10.

"Tasarruf ve Yerli Malı Haftası", Iktisat ve Tasarruf, C. 1, S. 1, Ocak 1931, s. 1.

"Tasarruf ve Yerli Malı Haftası", Kadro, Ocak 1932, s. 48.

"Vatandaş! Yeni İçtimai Ahlak, Yerli Malı Kullanmayı Emrediyor, Kim ki Yerli Malı Kullanmıyorsa, O, İçtimai Ahlaka Karşı Hareket Ediyor Demektir. Ona Kem Gözle Bak!", Iktisat ve Tasarruf, C.1, S. 4, Mart 1932, s. 4.

"Vatandaş! Tasarruf ve yerli malı haftası başladı, Bu hafta bütün yiyeceğini, içeceğini, giyeceğini, yerli malından al. Yerli malı satmayan dükkandan alışveriş etme", Milliyet, 12 Aralık 1930.

"Vatandaş! Yerli Yemiş Ye", İktisat ve Tasarruf, C. 1, S. 10, Eylül 1932, s. 4-5.

"Yerli Mallar Üzerinde İhtikâr Alçaklıktır", İktisat ve Tasarruf, C. 1, S. 5, Nisan 1932, s. 7.

"Yurddaş: Kurduğumuz Fabrikalar ve Yaptığımız Demir Yollar Hep Ulusun Biriktirme Gücüne Dayanır, Bu Gücü Arttırmak Senin Elindedir", Ulusal Ekonomi ve Artturma, C. 5, S. 7, Temmuz 1936, s. 3.

\section{Belge ve Zabitlar}

1930 Sanayi Kongresi Raporlar ve Zabitlar, İktisat ve Tasarruf Cemiyeti, Ankara 1930.

1931 Birinci Ziraat Kongresi İhtisas Raporlarl, İktisat ve Tasarruf Cemiyeti, Ankara 1931.

Cumhuriyet Halk Fırkasının Ana Vasıfları, CHP Üçüncü Büyük Kongre Zabıtları, Ankara 1931.

Milli İktisat ve Tasarruf Cemiyeti Nizamnamesi. Milli İktisat ve Tasarruf Cemiyeti, Ankara 1929.

DAB: 10. Tasarruf ve Yerli Malı Haftası'nın Kutlanma Şeklini Gösteren Tamim.

DAB: Ankara'da Toplanacak Ziraat Kongresine Katılımın Arttırılması.

DAB: Başbakan Şükrü Saraçoğlu'nun, Tasarruf ve Yerli Mallar Haftası ile İlgili Olarak, Ankara Halkevinde Sunduğu Nutuk .

DAB: Başbakan'ın, Tasarruf ve Yerli Malları Haftası Münasebeti ile Yaptığı Açılış Konuşması.

DAB: Milli İktisat ve Tasarruf Cemiyetine 2. Vakıf Apartmanındaki Yazıhanenin Kiralanması.

DAB: Milli iktisat ve Tasarruf Cemiyeti'nin 4. Tasarruf ve Yerli Malları Haftas1 Dolayısıyla Halkın Tasarrufa ve Yerli Mallarına Özendirilmesi Hususlarının Vaazlarda İşlenmesi Talebi.

DAB: Milli İktisat ve Tasarruf Cemiyetinin Çalışmalarına Yardımcı Olunması.

\section{History Studies}


DAB: Milli İktisat ve Tasarruf Cemiyeti'nin Gayesinin Halka tanıtılması İçin Minarelere Mahya Asılması ve Camilerde bu Kanunun Halka Anlatılması.

DAB: Milli İktisat ve Tasarruf Cemiyetinin Kamu Yararına Dernek Sayılması.

DAB: Milli İktisat ve Tasarruf Cemiyeti'ne Üye Kaydına Yardım Edilmesi.

DAB: Onuncu Tasarruf ve Yerli Malı Haftası Münasebetiyle Tasarruf Hakkında Yazılmış Hutbelerin Okunmass.

DAB: Tasarruf ve Yerli Malları Haftası'nda Halkevlerinde Yapılan Faaliyetler.

DAB: Tasarruf ve Yerli Malı Haftası Kutlamaları.

İNÖNÜ, İsmet, Türkiye Büyük Millet Meclisi Zabıt Ceridesi (3. Dönem), Cilt: 1, Ankara 12 Aralık 2019, s. 30-36. 